\title{
A magyar és a mandarin kínai hangrendszer összehasonlító elemzése a nyelvpedagógia szemszögéből"
}

A mandarin kínai nyelv (a továbbiakban egyszerüen: kínai nyelv) kiejtésének tanításához a hangtan fontos helyet foglal el a kínai mint idegen nyelv tanításában (Teaching Chinese as a Foreign Language, TCFL). A 20. század közepén Yuen Ren Chao (Zhao Yuanren 赵元任) tananyagként használta saját Mandarin Primer címü müvét, amikor Amerikában kínai nyelvet tanított: „Az oktatás jórészt a kiejtésről szól, azután térünk rá más vonatkozások tanítására". Akkoriban tehát a kiejtés tanítása fontos szerepet játszott. Az utóbbi idők kínainyelv-oktatási fellendülése során azonban a metodológia a különböző részterületeket tekintve egyenetlen fejlődést mutat. Egyes területeken számottevő előrelépés történt, de a kiejtés tanítása nincs ezek között. Nem csoda, hogy Lin Tao odáig ment, hogy kijelentse: „A kiejtés tanítása nem fejlődött. Ellenkezőleg: jelentős visszalépést mutat." ${ }^{2}$ Ez így talán túlzottan borúlátó, de valóban úgy fest, hogy nemcsak a kiejtés tanitása, hanem maga a kiejtés is a viszonylag kevéssé kutatott területek közé tartozik. Mindazonáltal az elmúlt évtizedekben egy sor értékes tanulmány látott napvilágot a kínai nyelv kiejtéséről és annak oktatási aspektusairól, amelyek jó része a kínai és más konkrét nyelvek összehasonlítását állította középpontba. E tanulmányunk ez utóbbi irányhoz szeretne hozzájárulni a kínai és a magyar hangrendszer pedagógiai célú összevetésével. Egy rövid átfogó bevezető után, amelyben a két nyelv általános különbségeit foglaljuk össze, egy olyan hangtani összevetést mutatunk be, amely kísérletet tesz arra is, hogy rámutasson: mely különbségekből eredhetnek jelentős problémák a kínaiul tanuló magyar anyanyelvüek számára.

A szerzők egyenlően járultak hozzá a tanulmány tartalmához, neveik ábécérendben jelennek meg.

Chao 1948: 23.

2 Lin Tao 1996: 18. 


\section{1. Általános ismertető}

A magyar nyelv az uráli (más megközelítésben: finnugor) nyelvcsaládba tartozó, elsősorban Kelet-Közép-Európában beszélt nyelv. Beszélőinek számát tekintve Európában a 12. legnagyobb nyelv. ${ }^{3}$ A beszélőközösség legnagyobb része Magyarországon él, de jelentős magyar ajkú kisebbségek élnek a környező országokban (Románia, Szlovákia, Szerbia, Horvátország, Ausztria, Szlovénia), valamint Észak-Amerikában (Egyesült Államok, Kanada), sőt Ausztráliában is - utóbbi esetben az elmúlt mintegy 130-140 év több nagy kivándorlási hullámának eredményeképp.

A magyar nemcsak Európa más (főleg indoeurópai gyökerü) nyelvétől különbözik jelentősen, hanem a többi uráli nyelvtől is: még a legközelebbi rokonoknak tartott obi-ugor nyelvek (a vogul és az osztják) is igencsak távol állnak a magyartól mind hangrendszerük, mind mondatszerkezetük, mind szókincsük tekintetében. ${ }^{4}$

A magyar tipológiailag agglutináló, szintaktikai szerkezeteinek egy része nem konfigurációs, ${ }^{5}$ prozódiája pedig szótagalapú. ${ }^{6}$ Szókincse igen sok jövevényszót tartalmaz.

A magyar nyelv számos változata közül e tanulmányunk azt veszi alapul, amelyet müvelt magyar köznyelvként ${ }^{7}$ szokás címkézni. Ez a változat nagymértékben megegyezik a mai budapesti beszélt nyelvvel, és a tanulmány alapját képező adatfelvételek és kísérletek alanyai is jellemzően ezt használják egymás közti, valamint oktatási kontextusbeli megnyilvánulásaikban. Eltér ugyanakkor ez a változat a hagyományosan magas presztízsủnek tekintett, de eredetét tekintve nem a budapesti köznyelvböl eredő standard irodalmi nyelvtöl, csakúgy, mint a különféle nyelvjárásoktól és szociolektusoktól.

A kínai nyelv a legáltalánosabban elfogadott nézet szerint ${ }^{8}$ a sino-tibeti nyelvcsalád egyik ágát képezi, beszélöközössége (amely a világon a legnagyobb: a Föld össznépességének mintegy egyötödének az anyanyelve) jórészt a mai Kínai Népköztársaság területén, Tajvanon, Hongkongban, Makaón, va-

Forrás: Ethnologue (https://www.ethnologue.com/statistics/size), idézve a Wikipedián (https://en.wikipedia.org/wiki/List_of_languages_by_number_of_native_speakers); utolsó hozzáférés: 2020.04.09.

Siptár-Törkenczy 2000: 13.

Ld. például Kiefer 1992; Kiefer-É. Kiss 1994; Kornai 1994.

Roach 1982; Crystal 1995.

Nádasdy 1985.

8 Például Matisoff 2003; Thurgood-LaPolla 2017. 
lamint egyes délkelet-ázsiai országokban (Malajzia, Indonézia, Szingapúr) él, de jelentős etnikai közösségeiket találjuk Észak-Amerika és Nyugat-Európa több országában, valamint Ausztráliában is. ${ }^{9}$ A kínai nyelv számos változata közül $1^{10}$ a külföldiek számára általában csupán kettőt tanítanak: a mandarint és a kantonit, de ezek közül is elsősorban az előbbit. A mandarin kínai számít elsődleges standardnak (mind a Népköztársaságban, mind Tajvanon), amelyet kínaiul a, ,普通话 pǔtōnghuà”, illetve „国语 guóyǔ”" ${ }^{11}$ elnevezésekkel illetnek. Ennek a változatnak van kiemelt társadalmi, politikai és kulturális státusa, ezt használják hivatalos kontextusokban, és mindenütt kötelezően tanítjáktanulják az iskolákban. Nyelvtana és szókincse az északi (más néven: mandarin) nyelvjárásokon és a modern írott nyelven alapszik, hangrendszere és kiejtése pedig a pekingi beszélt nyelven. Számos általánosabb címke („kínai”, „Chinese”, ,汉语 hànyǔ ” [szó szerint: a hanok nyelve], “中文 zhōngwén” [szó szerint: Kína írása/nyelve]) általános használatában tipikusan ezt a standard köznyelvet takarja.

Az agglutináló magyarral szemben a kínai nyelv izoláló jellegü, szintaxisa konfigurációs, amelyben a fő mondatösszetevők pozíciója kötött és jól meghatározott. Hangrendszerének egyik domináns jellegzetessége a tónusrendszer, fonémikus értékủ tónusokkal (részletesen ld. a 2.3.1. részt). Írásrendszere pedig logografikus-morfoszillabikus elemekből áll.

\section{A magyar és a kínai hangrendszer kontrasztív elemzése}

Ebben a részben összevetjük a magyar és a (mandarin) kínai hangrendszerét, rávilágítva mind a hasonlóságokra, mind a különbségekre, különös figyelemmel azokra a mozzanatokra, amelyek problémát okozhatnak a kínaiul tanuló magyar anyanyelvúek számára. Az elemző bemutatás az általános, rendszerszintü különbségek felvázolásával indul, majd a rendszer elemeinek (mással-

9 Hosszú időre nyúlik vissza a vita arról, hogy a „kínai nyelv” (egymástól a kölcsönös érthetetlenség szintjéig különböző) területi változatai egyetlen nyelv nyelvjárásai-e, vagy önálló nyelvek (Mair 1991, 2013; Chappell-Li 2017) - minthogy az ilyen megkülönböztetésnek nyelvészeti kritériuma lényegében nincs, a vita csak külsődleges (például politikai) alapon dönthető el, ezért nem kívánunk ebben állást foglalni, midőn itt pusztán az egyszerüség kedvéért az előbbivel konszonáns terminológiát használunk. Ld. például Li 1973; Norman 1988; Ramsey 1987.

11 Cikkünkben (az általános nemzetközi gyakorlatot követve) az úgynevezett pinjin átírást használjuk a kínai szavak és nevek latin betűs megjelenítésére. 
hangzók, magánhangzók, szupraszegmentális elemek) részletes vizsgálatával folytatódik. Záró részében pedig a problémás területeket összegezzük, a Pratorféle rangsorba ${ }^{12}$ elhelyezve őket.

Nagyon általános megközelítésben öt átfogó rendszerszintü különbséget figyelhetünk meg. Az első és legnyilvánvalóbb ezek közül az, hogy a kínai tonális nyelv, amelyben az egyes szótagok emelkedő, eső, eső-emelkedő és szinttartó dallama rendszeresen lexikai és esetenként nyelvtani jelentést, illetve funkciót hordoz - ez a jellegzetesség teljesen hiányzik a magyarból. A második rendszerszintü különbség az, hogy a magyar él a zöngés-zöngétlen oppozícióval, míg a kínai nem, ugyanakkor a kínai használja az aspirált-aspirálatlan szembenállást, amelyet viszont a magyar nem. A harmadik az, hogy a magánhangzó-hosszúság kontrasztív a magyarban, de nem az a kínaiban. A negyedik az, hogy a magyarban fonémikus különbség van a középső nyelvállású magán-

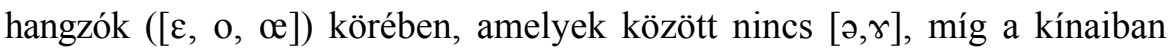
mindezen öt allofón egyetlen fonémát reprezentál. Az ötödik különbség pedig az, hogy ellentétben a kínaival, a magyarból hiányoznak a valódi félmagánhangzók, és ezzel együtt a nyíló/ereszkedő kettőshangzók (diftongusok). ${ }^{13}$

A következőkben az egyes beszédhangokat fogjuk megvizsgálni, kezdve a mássalhangzókkal, előbb nyelvenként külön-külön, majd képzési jegyeik (hely, mód) tekintetében összevetve a két nyelvbéli státusukat. Ezután a magánhangzók vizsgálata következik, majd a tónusoké, azután a szótagszerkezeté és végül a szupraszegmentális tulajdonságoké (hangsúly, intonáció). Ahol másképp külön nem jelezzük, ott a magyar hangrendszer ismertetésében Siptár és Törkenczy nemzetközileg is jól ismert munkáját ${ }^{14}$ követjük, míg a kínaira vonatkozó leírás Huang és Liao munkáján ${ }^{15}$ alapszik.

\subsection{A magyar és a kínai mássalhangzók kontrasztív vizsgálata}

A magyar mássalhangzó-rendszer 24 elemből áll: p, b, t, d, ty, gy, k, g, f, v, sz, z, s, zs, h, c, cs, dzs, m, n, ny, l, r, j / ly, fonetikai átírással: [p, b, t, d, c, J, k, g, f,

12 Prator 1967.

13 Ez alól kivételt képeznek egyes modern jövevényszavak, amelyek a forrásnyelv egyes diftongusait megőrizték, például: autó [auto:].

14 Siptár-Törkenczy 2000.

15 Huang-Liao 1991. 
$\left.\mathrm{v}, \mathrm{s}, \mathrm{z}, \int, 3, \mathrm{~h}, \mathrm{ts}, \mathrm{t} \int, \mathrm{d} 3, \mathrm{~m}, \mathrm{n}, \mathrm{n}, \mathrm{l}, \mathrm{r}, \mathrm{j}\right] .{ }^{16}$ Ezek egy része kilenc párt alkot, ahol a párok tagjai azonos helyen képzettek, de eltérnek zöngésség (azaz a hangszálak rezgése, illetve annak hiánya) tekintetében. E kilenc párt az 1. táblázat foglalja össze. A mássalhangzók további osztályozását a következő alrész tartalmazza részletesen.

\begin{tabular}{|l|l|}
\hline Zöngés mássalhangzók & $\mathrm{b}, \mathrm{d}, \mathrm{g}, \mathrm{v}, \mathrm{z}, \mathrm{3}, \mathrm{d} 3, \mathrm{~J}$ \\
\hline Zöngétlen mássalhangzók & $\mathrm{p}, \mathrm{t}, \mathrm{k}, \mathrm{f}, \mathrm{s}, \int, \mathrm{t} \int \mathrm{c}$ \\
\hline
\end{tabular}

1. táblázat. Zöngés és zöngétlen mássalhangzók a magyarban

A kínai mássalhangzókészlet 22 elemü, ezek: b, p, m, f, d, t, n, l, g, k, h, j, q, x, $\mathrm{zh}, \mathrm{ch}, \mathrm{sh}, \mathrm{r}, \mathrm{z}, \mathrm{c}, \mathrm{s}, \mathrm{ng}$, fonetikai jelekkel: [bo, $\mathrm{p}^{\mathrm{h}}, \mathrm{m}, \mathrm{f}, \mathrm{d}, \mathrm{t}^{\mathrm{h}}, \mathrm{n}, 1, \stackrel{\circ}{\mathrm{g}}, \mathrm{k}^{\mathrm{h}}, \chi$, $\left.\mathrm{t} \epsilon, \mathrm{t}^{\mathrm{h}}, \varphi, \mathrm{ts}, \mathrm{ts}{ }^{\mathrm{h}}, \mathrm{s}, \mathrm{z}_{\ominus} \mathrm{ts}, \mathrm{ts}{ }^{\mathrm{h}}, \mathrm{s}, \mathrm{y}\right]$. A magyarban látottakkal ellentétben itt nincs zöngésségi szembenállás, vannak ugyanakkor aspirációban különböző tagú párok: ezek tagjai szinte minden képzési jegyben azonosak (és egyaránt zöngétlenek), csupán a jellegzetes erős légkiáramlás (aspiráció, hehezet), valamint az artikulációt végző izmok feszessége (aspirált fortis vs. aspirálatlan lenis) különbözteti meg őket. A hat aspirált/aspirálatlan párt a 2. táblázat foglalja össze. A további kategorizációt és jellemzést e rész további alrészei fejtik ki.

\begin{tabular}{|l|l|}
\hline Aspirálatlan msh-k & $\mathrm{b}, \mathrm{d}, \stackrel{\circ}{\mathrm{g}}, \mathrm{ts}, \mathrm{ts}, \mathrm{t} \varphi$ \\
\hline Aspirált msh-k & $\mathrm{p}^{\mathrm{h}}, \mathrm{t}^{\mathrm{h}}, \mathrm{k}^{\mathrm{h}}, \mathrm{ts}^{\mathrm{h}}, \mathrm{ts} \mathrm{s}^{\mathrm{h}}, \mathrm{t} \varphi^{\mathrm{h}}$ \\
\hline
\end{tabular}

2. táblázat. Aspirálatlan és aspirált mássalhangzók a kínaiban

16 A $d z$ betűkombináció által jelölt hangszekvencia ([dz]) nem tekinthető egyetlen fonémának, illetve azt megvalósító egyetlen beszédhangnak (affrikátának), hiszen (a) sosem fordul elő morfémakezdő vagy mássalhangzó utáni pozícióban (a pénz típusú szavakbeli származtatott megjelenését leszámítva), (b) ahol pedig előfordul, ott csak gemináta (hosszú msh.) formában jelenhet meg (madzag, edzö, pi $[\mathrm{dz}] a$ ). Ezért nincs okunk ilyen mögöttes fonémát feltételezni (Siptár 1994: 207 skk.). 


\subsubsection{A magyar és kínai mássalhangzók kontrasztív elemzése képzési helyeik szerint}

\subsubsection{Labiálisok}

A magyar labiális mássalhangzók a következők: [b, p, m, f, v]; a hozzájuk leginkább hasonló kínai mássalhangzók: $\left[\mathrm{b}, \mathrm{p}^{\mathrm{h}}, \mathrm{m}, \mathrm{f}\right]$. Mindkét nyelvben találunk tehát bilabiális és labiodentális hangot, ezek képzésében a két nyelvben nincs érdemi különbség. A fent említett rendszerszintü különbségek azonban manifesztálódnak: a magyarban itt is megjelenik a zöngés-zöngétlen kontraszt, a kínaiban pedig az aspiráltsági/feszességi szembenállás, mindezek kölcsönös hiányával a másik nyelvben. Ebből eredően a kínaiból hiányzik a labiodentális réshang [f] zöngés párja: $[\mathrm{v}]$.

\subsubsection{Dentális/alveoláris zárhangok}

A magyar (alveo)dentális (v. laminodentális) zárhangok: [d, t, n, 1]; a kínaiban az ugyanezen képzési zónában artikulált zárhangok pedig: $\left[\mathrm{d}, \mathrm{t}^{\mathrm{h}}, \mathrm{n}, 1\right]$. E hangok képzésében is elsősorban a már említett rendszerszintü különbségeket találjuk (zöngésségi oppozíció a magyarban vs. aspirációs/feszességi kontraszt a kínaiban). Az [n] képzése ugyanakkor a kínaiban nem teljesen azonos szótagkezdő és szótagzáró pozícióban, ${ }^{17}$ ami nemcsak a reprodukció, hanem már a percepció (a különbség felfedezése) szintjén is nehézséget okoz a magyar nyelvtanulóknak, ugyanakkor a kétféle artikuláció egybeesése a legcsekélyebb zavart vagy értési nehézséget sem okozza. Egy másik érdekes mozzanat a dentális zengőhangok $([\mathrm{n}, 1])$ palatalizálódása a kínaiban elöl képzett felső magánhangzó ([i, y]) elött: $n i \rightarrow\left[\mathrm{n}^{\mathrm{j}} \mathrm{i}\right], l \ddot{u} \rightarrow\left[1^{\mathrm{j}} \mathrm{y}\right]$. A palatalizált $n$ (azaz [n $\left.{ }^{\mathrm{j}}\right]$ ) közel áll a magyar palatális nazális [n] hanghoz, így gyakran akként ejtik a nyelvtanulók, míg palatális laterális approximáns (azaz $[K]$ ) nincs a magyarban, és ezt a palatalizációt kevésbé érzékelik/reprodukálják.

17 Duanmu 2007: 24. 


\subsubsection{Dentális/alveoláris réshangok affrikáták}

Itt is csak a rendszeres különbségek érdemelnek említést: a zöngés oppozíció a magyarban, itt konkrétan csak a réshangok között: [s, $\mathrm{z}]$, és az aspirált fortis vs. aspirálatlan lenis pár a kínaiban [ts, $\left.\mathrm{ts}^{\mathrm{h}}\right]$.

\subsubsection{Palatálisok}

Az eddig látott képzési helyekkel ellentétben a palatális zóna jelentős különbségeket és ezekhez kötődő lényegi nehézségeket tartogat a nyelvtanulók számára, mivel az ebben a zónában képzett hangok mind a pontos képzési hely, mind a képzési módok tekintetében nagyon eltérnek. A magyarban laminális palatoalveoláris hangokat $\left[\mathrm{t} \int, \mathrm{d}_{3}, \int, 3\right]$ és azoktól fonémikusan különböző dorzopalatálisokat $[\mathrm{c}, \mathrm{f}]$ találunk, a szokásos zöngésségi kontraszttal. A kínaiban ezzel szemben egy nagyon sajátos típus, a kettősen artikulált laminoalveoláris dorzopalatálisok ${ }^{18}$ (a továbbiakban rövidítve: $l a-d p$ ): [t $\left.6, \mathrm{t} \epsilon^{\mathrm{h}}, \epsilon\right]$, valamint az ugyancsak viszonylag ritka posztalveoláris retroflexek [ts, $\left.\mathrm{ts}^{\mathrm{h}}, \mathrm{s}, \mathrm{z}\right]$ tartoznak ide. Mindkét kategóriában megjelenik a jól ismert aspirációs és feszességi kontraszt, a retroflex réshangoknál pedig teljesen egyedi módon egy zöngésségi oppozíció is. ${ }^{19}$ A nyelvtanulók kiejtési hibáinak talán legfőbb forrása, hogy szinte automatikusan asszociálják (és ezért helyettesítik is) a kínai retroflexeket a magyar palatoalveolárisokkal, a kínai $l a-d p$ mássalhangzókat pedig a magyar dorzopalatálisokkal.

\subsubsection{Velárisok}

A velárisok képzési helye azonos a két nyelvben, de a szokásos rendszeres különbség itt is megjelenik - a magyarban zöngés-zöngétlen kontrasztot találunk:

18 Ladefoged és Maddieson (1996: 150-153) ezeket palatalizált posztalveolárisokként kategorizálja: egy elsődleges posztalveoláris artikulációs gesztust egy másodlagos palatális approximáns gesztus kísér.

19 Az elmélet szintjén érdekes kérdés, hogy a fonetikailag sokak által zöngés retroflex réshangként (és így obstruensként) számon tartott hang ([z]) esetleg valójában valamiféle likvida vagy approximáns (és így szonoráns), amely esetben az egyetlen zöngésségi kontraszt a mandarin hangrendszerben tulajdonképpen csak látszólagos. A kérdést azonban e tanulmány kontextusában nem kell eldöntenünk, az egyszerüség kedvéért itt a ,zöngés réshang” megközelítés terminológiáját követjük. (A téma rövid tárgyalásáért ld. Duanmu 2007: 24.) 
[g] vs. [k], a kínaiban pedig laza aspirálatlan - feszes aspirált párt: [̊g] vs. [ $\left.\mathrm{k}^{\mathrm{h}}\right]$. A mandarinban csak szótagvégi helyzetben előforduló ${ }^{20}[\mathrm{y}]$ ugyanakkor problémákat okoz, mert bár a magyarban is létezik ez a hang, de nem fonémikusan (hanem csak a /n/ allofónjaként /g/ elött), így a magyar beszélők gyakran csak egy utána tett [g]-vel együtt „hajlandók” kiejteni: [ng] (ebben szerepe lehet egyébként annak is, hogy a pinjin átírás is - $n g$ betükombinációval jelöli ezt a hangot). A magyar tanulók figyelmét tehát határozottan irányítani kell, hogy tudatosítsuk bennük: hajlamosak önkéntelenül [g]-vel együtt kiejteni ezt a zárlati mássalhangzót, tehát igyekezzenek odafigyelve elhagyni ezt a szinte automatikus extraelemet, más szóval: a [yg] szekvencia ejtésében álljanak meg a [y]-nél.

\subsubsection{Posztvelárisok}

A két párhuzamba állítható hang jelentősen különböző artikulációjú: a magyarban glottális-laringális $[\mathrm{h}]$ réshang van, míg a standard kínaiban vagy uvuláris approximánsként $([\chi])$, vagy esetleg veláris réshangként $([\mathrm{x}])$ valósul meg a veláris zár- és zár-rés hangokkal a rendszer szintjén egy csoportot alkotó frikatíva. ${ }^{21}$ Bár a megértésben nem okoz nehézséget egyik irányban sem ez a különbség, illetve a másik nyelvre jellemző „idegenes” artikuláció, azért nem árt a nyelvtanulókat arra ösztönözni, hogy tudatosan, odafigyelve megfelelően képezzék ezt a hangot.

\subsubsection{A magyar és a kínai mássalhangzók kontrasztív elemzése a képzés módja szerint}

\subsubsection{A zárhangok és affrikáták „párosai”}

Itt ismét a második szisztematikus különbséget találjuk: a kínaiban a szokványos oppozíció egy-egy aspirálatlan lenis ( $\mathrm{kb}$. mint az angol zöngés obstruensek zöngétlenedett változata) és aspirált fortis hang között áll fenn. Mindkettő

20 Számos kínai dialektusban ugyanakkor szótagkezdetben is találunk veláris nazális mássalhangzót (Norman 1988; Li 2007).

21 Egyes kínai nyelvjárásokban, például a sanghajiban (Chen-Gussenhoven 2015: 325) ugyanakkor szintén a magyarhoz hasonló gégeföi réshangként valósul meg ez a fonéma. 
egyértelmüen zöngétlen, bár az aspirálatlan tagok egyes környezetekben zöngésedhetnek, különösen tónustalan és hangsúlytalan szótagokban - ennek jellemző példája a 的 jelzői viszonyszó: [di] $\rightarrow$ [də] $\rightarrow$ [də].

A magyarban nincs érdemben hasonló fortis lenis különbség a zárhang-, illetve zár-rés hang párok tagjai között: mindkét tag közepes fokú feszességgel rendelkezik (,félfortis”), és aspirálatlan, ugyanakkor világos zöngésségi kontrasztban állnak. A magyar nyelvtanulók gyakran azonosítják a mandarin aspirálatlan fortis mássalhangzókat anyanyelvük félfortis zöngétlen mássalhangzóival, minek okán a mandarinbeli párok tagjai könnyen egybemosódhatnak. A gyakorlatban ez azonban nem vezet jelentős problémához, minthogy bár a magyarban teljesen hiányzik az aspiráció jelensége, ha a tanuló figyelmét felhívják erre a tulajdonságra és oppozícióra, könnyen képesek mind felismerni, mind reprodukálni. Egy másfajta probléma forrása ugyanakkor a pinjin átírás: a pinjinben az aspirálatlan zöngétlen zárhangokat olyan betük jelölik $(b, d, g)$, amelyek a magyarban zöngés mássalhangzók grafémái, és ez a tanulók egy részét hajlamosítja e mandarin hangok zöngés ejtésmódjára. Fel kell tehát hívni a figyelmüket a mandarin hangok zöngétlen voltára, másfelől pedig gyakoroltatni kell velük e hangok lenis ejtését, azaz azt, hogy képzésükkor az artikulációban részt vevő izmok lazák maradjanak.

\subsubsection{A rímkezdeti és rímvégi félmagánhangzók}

A mandarinban három ilyen hangot találunk: [j, w, 4], ezek mindegyike elöfordul rímkezdő pozícióban, de csak az előbbi kettő jelenik meg rímvégi (kóda-) helyzetben. A magyarban ezek közül csak a [j] található meg, lényegében mássalhangzói szerepben, egy zöngétlen allofónnal: [ç] zöngétlen környe-

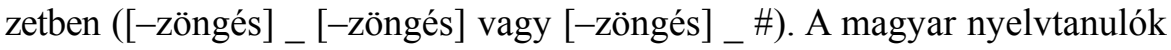
számára tehát be kell mutatni az [u] és az [y] magánhangzók siklóhangkénti megvalósulásaként szereplő [w], illetve [บ] hangokat. A [w] ritkán okoz problémát, valószínüleg abból eredően, hogy a Magyarországon elsődlegesen tanult idegen nyelvben, az angolban is van egy hasonló félmagánhangzó, bár arról is említést kell tenni, hogy az angol [w] és a kínai [w] nem teljesen azonos. ${ }^{22}$ $\mathrm{Az}[\mathrm{Y}]$, amelynek nincs máshonnan ismerhető „rokona”, már némileg nehezebb ügy. Legfóképpen arra kell figyelni, hogy a tanuló ne essen abba a csap-

22 Pontosabban a pekingi nyelvváltozatban a $w$-vel jelölt hang tipikusan labiodentális (nem pedig bilabiális ejtésü) ejtésű: [v], kivéve -o előtt (Duanmu 2007: 23). 
dába, hogy a (magyarban is meglevő) [y] teljes értékü magánhangzóval helyettesíti (ez egyébként a másik két siklóhanggal is előfordulhat, azaz [j] helyett [i]-t, [w] helyett rövid [u]-t hajlamosak ejteni a rímkezdeti pozícióban), ami diftongus helyett magánhangzó-szekvenciát eredményez.

\subsubsection{Az artikulációs tulajdonságok táblázatai}

A mássalhangzóknak a képzés helye és módja tekintetében való osztályozását a magyarban és a kínaiban az alábbi táblázatok foglalják össze:

\begin{tabular}{|c|c|c|c|c|c|c|c|c|c|c|c|}
\hline & \multicolumn{6}{|c|}{ Obstruensek } & \multicolumn{4}{|c|}{ Szonoránsok } \\
\hline & & \multicolumn{2}{|c|}{ Zárhangok } & \multicolumn{2}{|c|}{ Affrikáták } & \multicolumn{2}{|c|}{ Réshangok } & \multirow{3}{*}{$\frac{\text { Nazálisok }}{\text { Zgs }}$} & \multirow{2}{*}{\multicolumn{3}{|c|}{$\begin{array}{c}\text { Likvidák } \\
\text { Zgs }\end{array}$}} \\
\hline & & \multirow[t]{2}{*}{ Zgs } & \multirow[t]{2}{*}{ Zgtlen } & \multirow[t]{2}{*}{ Zgs } & \multirow[t]{2}{*}{ Zgtlen } & \multirow[t]{3}{*}{ Zgs } & \multirow[t]{2}{*}{ Zgtlen } & & & & \\
\hline & & & & & & & & & Laterális & Pergố & $\begin{array}{l}\text { Approxi- } \\
\text { máns }\end{array}$ \\
\hline \multirow[b]{2}{*}{ Labiális } & Bilabiális & $\mathrm{b}$ & $\mathrm{p}$ & & & & & $\mathrm{m}$ & & & \\
\hline & $\begin{array}{l}\begin{array}{l}\text { Labio- } \\
\text { dentális }\end{array} \\
\text { d }\end{array}$ & & & & & $\mathrm{v}$ & $\mathrm{f}$ & & & & \\
\hline \multirow{2}{*}{$\begin{array}{l}\text { Dentális/ } \\
\text { alveoláris }\end{array}$} & $\begin{array}{l}\text { Lamino- } \\
\text { dentális }\end{array}$ & d & $\mathrm{t}$ & & & & & $\mathrm{n}$ & 1 & $\mathrm{r}$ & \\
\hline & $\begin{array}{l}\text { Lamino- } \\
\text { alveoláris }\end{array}$ & & & & $\begin{array}{l}\text { ts } \\
\text { (c) }\end{array}$ & $\mathrm{z}$ & $\begin{array}{c}\mathrm{s} \\
(s z)\end{array}$ & & & & \\
\hline \multirow{2}{*}{ Palatális } & $\begin{array}{l}\text { Palato- } \\
\text { alveoláris }\end{array}$ & & & $\begin{array}{c}\overline{d y} \\
(d z s)\end{array}$ & $\begin{array}{c}\widehat{t s} \\
(c s)\end{array}$ & $\begin{array}{c}3 \\
(z s)\end{array}$ & $\int_{(s)}$ & & & & \\
\hline & $\begin{array}{l}\text { Dorzo- } \\
\text { palatális }\end{array}$ & $\begin{array}{c}f \\
(g y)\end{array}$ & $\begin{array}{c}\mathrm{c} \\
\text { (ty) }\end{array}$ & & & & & $\begin{array}{c}\mathrm{n} \\
(n y)\end{array}$ & & & $\begin{array}{c}\mathrm{j} \\
(j \wedge y)^{24}\end{array}$ \\
\hline \multicolumn{2}{|l|}{ Veláris } & $\mathrm{g}$ & $\mathrm{k}$ & & & & & & & & \\
\hline \multicolumn{2}{|c|}{ Posztveláris } & & & & & & $\mathrm{h}$ & & & & \\
\hline
\end{tabular}

3. táblázat. A magyar mássalhangzók osztályozása (Siptár-Törkenczy 2000 alapján) ${ }^{23}$

23 A táblázat IPA-jelekkel adja meg a hangokat; ahol az írásmód ettől eltérő, ott azt zárójelben dölttel adjuk meg.

A magyar ortográfia archaikus mozzanataként a $\mathrm{j}$ hangot egyes szavakban $j$, más szavakban ly kódolja írásban. 


\begin{tabular}{|c|c|c|c|c|c|c|c|c|c|}
\hline & \multicolumn{6}{|c|}{ Obstruensek } & \multicolumn{2}{|c|}{$\begin{array}{l}\text { Szonoránsok } \\
\text { (mind zöngés) }\end{array}$} \\
\hline & & \multicolumn{2}{|c|}{ Zárhangok } & \multicolumn{2}{|c|}{ Affrikáták } & \multicolumn{2}{|c|}{ Réshangok } & \multirow[t]{2}{*}{ Nazálisok } & \multirow{2}{*}{$\begin{array}{l}\text { Likvida } \\
\text { (Laterális) }\end{array}$} \\
\hline & & Aspirálatlan & Aspirált & Aspirálatlan & Aspirált & Zgtlen & Zgs & & \\
\hline \multirow[t]{2}{*}{ Labiális } & Bilabiális & $\begin{array}{l}\mathrm{b} \\
\text { (b) }\end{array}$ & $\begin{array}{l}\mathrm{p}^{\mathrm{h}} \\
(p)\end{array}$ & & & & & $\mathrm{m}$ & \\
\hline & Labiodentális & & & & & f & & & \\
\hline \multirow[t]{3}{*}{$\begin{array}{l}\text { Dentális/ } \\
\text { alveoláris }\end{array}$} & Apiko-dentális & & & $\begin{array}{l}\overparen{\mathrm{ts}} \\
(z)\end{array}$ & $\begin{array}{l}\mathrm{ts}^{\mathrm{h}} \\
\text { (c) }\end{array}$ & $\mathrm{s}$ & & & \\
\hline & $\begin{array}{l}\text { Apiko- } \\
\text { alveoláris }\end{array}$ & $\begin{array}{l}\text { d } \\
\text { (d) }\end{array}$ & $\begin{array}{l}\mathrm{t}^{\mathrm{h}} \\
(\mathrm{t})\end{array}$ & & & & & $\mathrm{n}$ & 1 \\
\hline & $\begin{array}{l}\text { Apiko-poszt- } \\
\text { alveoláris } \\
\text { (retroflex) }\end{array}$ & & & $\begin{array}{l}\overparen{\mathrm{t}} \\
(z h)\end{array}$ & $\begin{array}{l}\mathrm{tS}^{\mathrm{h}} \\
(\mathrm{ch})\end{array}$ & $\begin{array}{l}\$ \\
(s h)\end{array}$ & $\begin{array}{l}\mathrm{z} \\
(r)\end{array}$ & & \\
\hline \multicolumn{2}{|c|}{$\begin{array}{l}\text { Alveoláris-palatális kettősen } \\
\text { artikulált }(l a-d p)\end{array}$} & & & $\begin{array}{l}\overparen{\mathrm{t}_{6}} \\
\text { (j) }\end{array}$ & $\begin{array}{l}\mathrm{tG}^{\mathrm{h}} \\
(q)\end{array}$ & $\begin{array}{l}6 \\
(x)\end{array}$ & & & \\
\hline \multicolumn{2}{|l|}{ Veláris } & $\begin{array}{l}\stackrel{\circ}{g} \\
(g)\end{array}$ & $\begin{array}{l}\mathrm{k}^{\mathrm{h}} \\
(\mathrm{k})\end{array}$ & & & & & $\begin{array}{c}\mathrm{n} \\
(n g)\end{array}$ & \\
\hline \multicolumn{2}{|c|}{ Posztveláris } & & & & & $\begin{array}{l}x / \mathrm{x} \\
\text { (h) }\end{array}$ & & & \\
\hline
\end{tabular}

4. táblázat. A mandarin mássalhangzók osztályozása (Huang-Liao 1991 alapján) ${ }^{25}$

\subsection{A magyar és a kínai magánhangzók kontrasztív elemzése}

A magyarban 14 magánhangzó-fonéma van, ezek: a, á, e, é, i, í, o, ó, ö, ő, u, ú, ü, ü, fonetikai átírással rendre: $[0, \mathrm{a}: \varepsilon, \mathrm{e}: \mathrm{i}, \mathrm{i}:, \mathrm{o}, \mathrm{o}:,, \varnothing \mathrm{x}, \mathrm{u}, \mathrm{u}: \mathrm{y}$, y:]. Az alábbi táblázat hosszúság tekintetében osztályozza őket:

\begin{tabular}{|l|l|}
\hline Rövid magánhangzók & o, $\varepsilon$, i, o, ø, u, y \\
\hline Hosszú magánhangzók & a: e: e, i: , o:, ø: u: u: y: \\
\hline
\end{tabular}

5. táblázat. Rövid és hosszú magánhangzók a magyarban

A nyelv horizontális elhelyezkedése alapján megkülönböztetünk elöl képzett ('magas') és hátul képzett ('mély’) magánhangzókat, ld. a következő táblázatot. A további osztályozásra később térünk ki.

\begin{tabular}{|l|l|}
\hline Elöl képzett magánhangzók & $\varepsilon, \mathrm{e}: \mathrm{i}, \mathrm{i}:,, \varnothing, \varnothing:, \mathrm{y}, \mathrm{y}:$ \\
\hline Hátul képzett magánhangzók & o, a: , o, o: $, \mathrm{u}, \mathrm{u}:$ \\
\hline
\end{tabular}

6. táblázat. Elöl képzett és hátul képzett magánhangzók a magyarban

25 A táblázat IPA-jelekkel adja meg a hangokat; ahol a pinjin írásmód ettől eltér, ott azt zárójelben dőlttel adjuk meg. 
A kínai magánhangzók elemzésében Huang és Liao 39 rímet különböztet meg. ${ }^{26}$ A bennük megjelenő magán- és mássalhangzók kompozíciós sémája szerint ezek négy nagy csoportba oszthatók:

- monoftongusok: $\quad$ a [a], o [o], ${ }^{27}$ e $[\gamma]$, ê $[\varepsilon],{ }^{28}$ i [i], u [u], ü [y], -i $[1],{ }^{29}-\mathrm{i}\left[\mathrm{\tau},{ }^{30}\right.$ er [r]

- diftongusok: ai [aj], ei [ej], ao [av], ou [oo], ia [ja], ie [je], ua [wa], uo [wo], üe [чع]

- triftongusok:

iao [jav], iou [jov], uai [waj], uei [wej]

- nazális végü rímek: an [an], en [ən], ian [jعn], uan [wan], üan [yən], in [in], uen [wən], ün [yn], ang [ay], iang [jay], uang [way], eng [ə]], ing [i门], ueng [wəy], ong [ชy], iong [joy]

A hagyományos kínai hangtanban a rím három pozíciót tartalmaz: egy rímkezdeti siklóhangét, egy főmagánhangzóét és egy rímzáró elemét (siklóhang v. nazális v. retroflex zárlat); ezek közül csak a fömagánhangzóé van kötelezően kitöltve, a másik kettő üres is lehet. Két példán (普通话 pǔtōnghuà 'köznyelv' és 想 xiăng 'gondol') illusztráljuk ezt az alábbi táblázatban.

26 Huang-Liao 1991. A kínai fonetikai-fonológiai hagyomány nem szegmentumokat, hanem rímeket osztályoz, amelynek gyökerei a kínai szótagszerkezet merevségében rejlenek, ezért itt mi is ebből a perspektívából indulunk ki. Másfelől a hagyományos kínai hangtani osztályozás nem minden esetben felel meg a modern nyugati nyelvtudomány fonémikus szemléletének, így az allofóniák felismerését és osztályozását Huang és Liao sem tekinti célnak, a jelen tanulmány céljainak azonban összességében ez a szemlélet e hiányosságaival együtt is jobban megfelel, mint egy „nyugati” alapú fonémikus elemzés, amennyiben az utóbbi kevésbé képes megragadni a kínai hangrendszer erős rímalapúságát.

Csak indulatszavakban fordul elö.

Csak indulatszavakban fordul elö.

29 Csak apikodentális affrikáta vagy réshang után.

30 Csak retroflex affrikáta/réshang után. 


\begin{tabular}{|c|c|c|c|c|}
\hline Szótag & Rím & $\begin{array}{c}\text { Rímkezdeti } \\
\text { elem }\end{array}$ & $\begin{array}{c}\text { Fómagán- } \\
\text { hangzó }\end{array}$ & $\begin{array}{c}\text { Rímzáró } \\
\text { elem }\end{array}$ \\
\hline pǔ & -ǔ & & $\mathrm{u}$ & \\
\hline tōng & -ōng & & $\mathrm{U}$ & $\mathrm{y}$ \\
\hline huà & -uà & $\mathrm{w}$ & $\mathrm{a}$ & \\
\hline xiăng & -iăng & $\mathrm{j}$ & $\mathrm{a}$ & $\mathrm{y}$ \\
\hline
\end{tabular}

7. táblázat. A rím pozíciói a kínaiban

\subsubsection{A magyar és a kínai monoftongusok kontrasztív elemzése}

Mint az imént számba vettük, a magyarban 14, a kínaiban 10 monoftongikus elem van. Alább mindkét rendszert a szokásos trapéz alakú magánhangzódiagramban elhelyezve szemléltetjük. ${ }^{31}$

A magas nyelvállású hangok az ábrán felül, az alacsony nyelvállásúak alul, az elöl képzettek bal felől, a hátul képzettek jobb felől jelennek meg. Az ajakkerekítés szerinti párok tagjai ugyanabban a pozícióban szerepelnek.
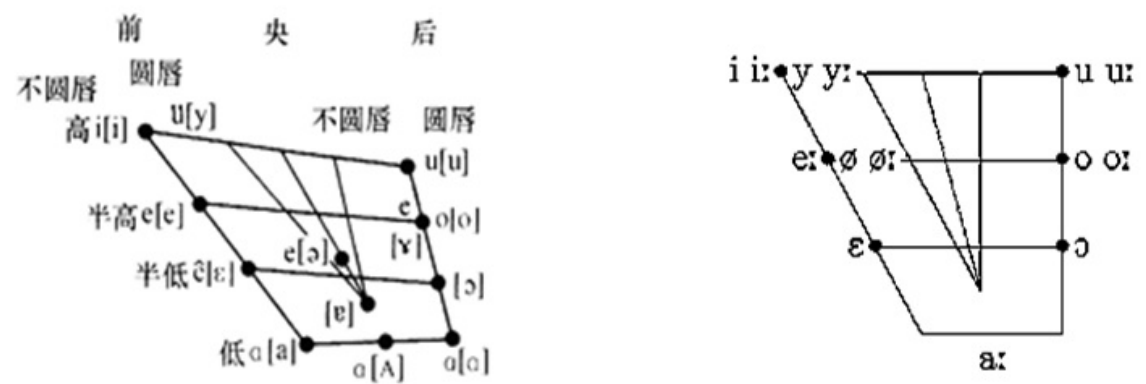

1. ábra. A mandarin kínai (balról) és a magyar (jobbról) magánhangzó-diagram ${ }^{32}$

31 A magánhangzótér ilyen grafikus reprezentációja Jones (1917) óta bevett.

32 A kínai ábrában a monoftongusokon kívül néhány diftongus-összetevő is szerepel $([\partial, \mathrm{e}, \Lambda, \mathrm{a}, \mathrm{\jmath}])$, viszont az [i] pozicionális variánsai $[1, \imath]$ nem. 
A magyar magánhangzók részletes jellemzését az alábbi táblázat tartalmazza: ${ }^{33}$

\begin{tabular}{|c|c|c|c|}
\hline \multirow{2}{*}{$\begin{array}{l}\text { Graféma } \\
\text { és IPA-jel }\end{array}$} & \multirow{2}{*}{$\begin{array}{c}\text { Ajak- } \\
\text { kerekítés }\end{array}$} & \multicolumn{2}{|c|}{ Nyelvállás } \\
\hline & & horizontális dimenzió & vertikális dimenzió \\
\hline $\mathrm{a}[\mathrm{o}]$ & $++^{34}$ & hátsó & alsó-közép \\
\hline á [a:] & - & középső & alsó \\
\hline $\mathrm{e}[\varepsilon]$ & - & elülső & alsó-közép \\
\hline é [e:] & - & elülső & felső-közép \\
\hline $\mathrm{i}[\mathrm{i}]$ & - & elülső & felső \\
\hline í [i:] & - & elülső & felső \\
\hline $\mathrm{o}[\mathrm{o}]$ & + & hátsó & középső \\
\hline ó [o:] & + & hátsó & felső-közép \\
\hline$\ddot{0}[\varnothing]$ & + & elülső & középső \\
\hline ö [Ø:] & + & elülső & felső-közép \\
\hline $\mathrm{u}[\mathrm{u}]$ & + & hátsó & felső \\
\hline ú [u:] & + & hátsó & felső \\
\hline$\ddot{u}[\ddot{u}]$ & + & elülső & felső \\
\hline ü [ü:] & + & elülső & felső \\
\hline
\end{tabular}

8. táblázat. A magyar magánhangzók nyelvállás és ajakkerekités szerinti osztályozása

33 Siptár-Törkenczy 2000.

34 Siptár és Törkenczy (2000) szerint, de ez a kérdés hagyományosan vitatott a magyar hangtanban. 
A kínai magánhangzók osztályozását pedig a következő táblázat tartalmazza: ${ }^{35}$

\begin{tabular}{|c|c|c|c|}
\hline \multirow{2}{*}{$\begin{array}{l}\text { Pinjin jel } \\
\text { és IPA-jel }\end{array}$} & \multirow{2}{*}{$\begin{array}{c}\text { Ajak- } \\
\text { kerekítés }\end{array}$} & \multicolumn{2}{|c|}{ Nyelvállás } \\
\hline & & horizontális dimenzió & vertikális dimenzió \\
\hline $\mathrm{a}[\mathrm{a}]$ & - & középső & alsó \\
\hline $\mathrm{a}[\mathrm{a}]$ & - & hátsó & alsó \\
\hline o [o] & + & hátsó & felső-közép \\
\hline $\mathrm{e}[\gamma]$ & - & hátsó & felső-közép \\
\hline $\mathrm{e} / \hat{\mathrm{e}}[\varepsilon]^{36}$ & - & elülső & alsó-közép \\
\hline $\mathrm{e}[\mathrm{e}]$ & - & elülső & felső-közép \\
\hline e [ə] & - & középső & középső \\
\hline $\mathrm{i}[\mathrm{i}]$ & - & elülső & felső \\
\hline $\mathrm{i}[1]$ & - & középső & felső \\
\hline $\mathrm{i}[\mathrm{q}]$ & - & középső (retroflex) & felső \\
\hline $\mathrm{u}[\mathrm{u}]$ & + & hátsó & felső \\
\hline $\mathrm{o}[\mathrm{v}]$ & + & hátsó(-középső) & felső-közép \\
\hline ü [y] & + & elülső & felső \\
\hline $\operatorname{er}[\boldsymbol{\gamma}]$ & - & középső (retroflex) & középső \\
\hline
\end{tabular}

9. táblázat. A kinai magánhangzók nyelvállás és ajakkerekités szerinti osztályozása

A fenti táblázat egyes elemei pozicionális variánsok (allofónok), így például az [a] és az [a] hangok egyetlen /a/ fonéma allofónjai, ${ }^{37}$ az $[o, \gamma, e, \varepsilon$, , $]$ han-

35 Huang-Liao 199.

36 Egyetlen rímben (-ian $[\mathrm{j} \varepsilon \mathrm{n}]) ~ a$ betü jelöli a pinjinben. 
gok $^{38}$ szintén egyetlen allofónikus rendszert alkotnak, az [i, 1, , ] hangok ugyancsak egyetlen /i/ fonéma alternatív megvalósulásai, és a fömagánhangzóként megjelenő $[\mho]$ hangot is lehetséges és érdemes az [u] allofónikus párjának tekinteni. Az allofónikus viszonyokat az alábbi táblázat foglalja össze:

\begin{tabular}{|c|c|c|}
\hline $\begin{array}{l}\text { Magánhangzó } \\
\text {-fonéma }\end{array}$ & Allofónok & Meghatározó környezetek (rímek) \\
\hline \multirow[t]{2}{*}{$/ \mathrm{a} /$} & [a] & a [a], ia [ja], ua [wa], ai [ai], an [an] \\
\hline & [a] & ao [av], ang [ay] \\
\hline \multirow[t]{5}{*}{$/ \mathrm{e} /$} & [e] & ei [ei] \\
\hline & {$[\varepsilon]$} & 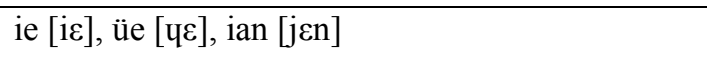 \\
\hline & [ə] & en [ən], eng [əу], üan [Чən] \\
\hline & [o] & uo [wo], ou [ov], o [o] ${ }^{39}$ \\
\hline & {$[\gamma]$} & $\mathrm{e}[\gamma]$ \\
\hline \multirow[t]{3}{*}{$/ \mathrm{i} /$} & [i] & $\begin{array}{l}\text { ji [tci], qi [te }{ }^{\mathrm{h}} \mathrm{i} \text { ], xi [ci], valamint i [i] amikor nem } \\
\text { retroflex v. alveodentális obstruens után áll }\end{array}$ \\
\hline & [1] & zi [ts1], ci [ts 1 h], si [s1] \\
\hline & [थ] &  \\
\hline \multirow[t]{2}{*}{$/ \mathrm{u} /$} & {$[\mathrm{u}]$} & $\mathrm{u}[\mathrm{u}]$ \\
\hline & [v] & ong [ひ门] \\
\hline
\end{tabular}

10. táblázat. Allofóniák a kínai magánhangzórendszerben

37 Egyes elemzések egy harmadik /a/ allofónt is felvesznek: [ $\Lambda$, nyílt szótagokban, elkülönítve a nazálisok és siklóhangok elötti helyzetben előforduló [a, a]-tól - a különféle nézetek áttekintéséért ld. Duanmu (2007: 38-40)-t. Mi ezt a megkülönböztetést itt nem tartjuk érdeminek.

38 Ez egyfelől (főleg az [o] tekintetében) némileg vitatott, bár kiegészítő eloszlásuk és az a tény, hogy ezek (és csak ezek) a nem retroflex középmagas nyelvállású hangok, erös érv amellett, hogy egyetlen allofónikus rendszerbe állítsuk öket, másfelöl viszont azzal az apró megszorítással igaz, hogy ,indulatszavak kivételével”, azokban ugyanis $[o],[\gamma]$ és $[\varepsilon]$ kontrasztban állnak.

39 Nyílt szótagban, ahol a fömagánhangzó után semmilyen siklóhang vagy zárlati mássalhangzó nem áll, a megelőző elemen múlik, hogy [o] vagy [r] lesz a megjelenő variáns: labiális mássalhangzók ([b, $\left.\left.\mathrm{p}^{\mathrm{h}}, \mathrm{m}, \mathrm{f}\right]\right)$ és veláris labiális siklóhang ([w]) után áll [o], máshol pedig $[\gamma]$. 
A további elemzésekhez hasznos, ha egyetlen közös táblázatba foglalva is szemléltetjük a magyar és a kínai magánhangzórendszereket: ${ }^{40}$

\begin{tabular}{|c|c|c|c|c|c|c|c|c|c|}
\hline & \multicolumn{5}{|c|}{ Nyelvháti magánhangzó } & \multirow{4}{*}{$\begin{array}{c}\begin{array}{c}\text { Retroflex } \\
\text { magánhangzó }\end{array} \\
\text { középső } \\
\text { kerekítetlen }\end{array}$} & \multicolumn{2}{|c|}{$\begin{array}{c}\text { Apikális } \\
\text { magánhangzó }\end{array}$} \\
\hline & & \multicolumn{2}{|c|}{ elülső } & \multirow{2}{*}{$\begin{array}{l}\text { középsó } \\
\text { kerekí- } \\
\text { tetlen }\end{array}$} & \multicolumn{2}{|c|}{ hátsó } & & \multirow[t]{2}{*}{ elülső } & \multirow[t]{2}{*}{ hátsó } \\
\hline & & $\begin{array}{l}\text { kerekí- } \\
\text { tetlen }\end{array}$ & kerekített & & $\begin{array}{l}\text { kerekí- } \\
\text { tetlen }\end{array}$ & kerekített & & & \\
\hline \multirow{2}{*}{$\begin{array}{l}\text { felső } \\
\text { nyelvállású }\end{array}$} & $\mathrm{M}$ & $\begin{array}{l}\text { i [i], } \\
\mathrm{i}[\mathrm{i}:]\end{array}$ & $\begin{array}{l}\text { ü [y], } \\
\text { ü [y:] }\end{array}$ & & & $\begin{array}{l}\mathrm{u}[\mathrm{u}] \\
\mathrm{u}[\mathrm{u}:]\end{array}$ & & & \\
\hline & $\mathrm{K}$ & $i[\mathrm{i}]$ & $\ddot{\mathrm{u}}[\mathrm{y}]$ & & & $\mathrm{u}[\mathrm{u}]$ & & $-\mathrm{i}[\mathrm{l}]$ & $-\mathrm{i}[\mathrm{\gamma}]$ \\
\hline \multirow[b]{2}{*}{$\begin{array}{l}\text { felső-közép } \\
\text { nyelvállású }\end{array}$} & $\mathrm{M}$ & é [e:] & ö [ø:] & & & ó [o:] & & & \\
\hline & $\mathrm{K}$ & $\mathrm{e}[\mathrm{e}]$ & & & $\mathrm{e}[\mathrm{\gamma}]$ & $\begin{array}{l}\text { o [o], } \\
\mathrm{o}[\mathrm{v}]\end{array}$ & & & \\
\hline \multirow{2}{*}{$\begin{array}{l}\text { középső } \\
\text { nyelvállású }\end{array}$} & $\mathrm{M}$ & & $\ddot{O}[\varnothing]$ & & & o [o] & & & \\
\hline & $\mathrm{K}$ & & & e [ə] & & & $\operatorname{er}\left[{ }^{2}\right]$ & & \\
\hline \multirow{2}{*}{$\begin{array}{l}\text { alsó-közép } \\
\text { nyelvállású }\end{array}$} & $\mathrm{M}$ & $\mathrm{e}[\varepsilon]$ & & & & $\mathrm{a}$ [0] & & & \\
\hline & $\mathrm{K}$ & $\mathrm{e}[\varepsilon]$ & & & & & & & \\
\hline \multirow{2}{*}{$\begin{array}{l}\text { alsó } \\
\text { nyelvállású }\end{array}$} & $\mathrm{M}$ & & & á [a:] & & & & & \\
\hline & $\mathrm{K}$ & & & $\mathrm{a}[\mathrm{a}]$ & $a[a]$ & & & & \\
\hline
\end{tabular}

11. táblázat. A magyar (M) és a kínai (K) magánhangzók összevető táblázata

Az alábbiakban a lényegi eltéréseket vesszük szemügyre.

\subsubsection{A magas nyelvállású magánhangzók}

A magyarban ezek: [i, y, u, i:, y:, u:], a kínaiban pedig: [i, y, l, ?, u]. A hoszszúság mint fonémikus kontrasztot adó tényező tekintetében szisztematikus különbség van a két nyelv között (mint ezt már korábban is említettük). Ettöl eltekintve az [i, y, u] elemek lényegében teljesen azonosak a két nyelvben. A további kínai /i/ allofónok ([1, ح]) nincsenek meg a magyarban, ám az [i]-től és [y]-től való különbözőségüket könnyen és jól érzékelik a magyar nyelvtanulók. Az artikuláció oldalán a lényegi mozzanat, amelyet meg kell tanítanunk nekik, az az, hogy képzésükkor a nyelv pontosan ugyanabban a pozícióban és állapotban marad, ahová és ahogy az őket megelőző mássalhangzó képzéséhez helyeztük.

\subsubsection{A középső nyelvállású magánhangzók}

A magyarban ezek: [ $\varepsilon, \varnothing$ o, e:, ø:, o:], a kínaiban pedig: [ $\varepsilon, \mathrm{e}, \mathrm{o}, \mathrm{U}, \gamma, \mathrm{Y}]$. Némely hangok teljesen megegyeznek, így például a magyar [ $\varepsilon]$-nek (például hülye) teljesen megfelel a kínai -üe rímbeli főmagánhangzó: 月 [уع], vagy a hosszúságtól elvonatkoztatva a magyar [o]-nak (például torr) a kínai -uo rím-

40 Részben Huang-Liao 1991; valamint Siptár-Törkenczy 2000 alapján. 
beli [o]: 多 [dọo]. Más magánhangzók esetében azonban jellegzetes különbségeket és ezekből eredő problémákat találunk. Egy ilyen példa a kínai -ong rím magánhangzója ([ซ]), amely kb. úgy magyarázható a magyar nyelvtanulóknak, hogy a képzés helye tekintetében „félúton” helyezkedik el a magyar [o] és $[\mathrm{u}]$ hangok között. A magyar beszélők zöme ezt a hangot a magyar $[\mathrm{u}]-$ val azonosítja, akként érzékeli, és magától ritkán veszi észre a különbséget köztük, de mihelyt felhívják rá a figyelmüket, semmi további nehézséget nem szokott okozni sem az azonosítása, sem a megfelelő artikulációs reprodukálása. $A[\gamma]$ hang megtanulása viszont szinte minden esetben problémát okoz. A magyarok többsége a magyar rövid [ø] hosszú változataként érzékeli, és ezt próbálja artikulációsan is előállítani - tévesen, a két hang ugyanis jelentősen eltér, a nyelvállás magasságát leszámítva: a kínai hátul képzett, kerekitetlen $[\curlyvee]$ helyett a magyarból átvitt elöl képzett kerekitett [ø] hangot produkálják. Ráadásul tapasztalataink szerint a magánhangzók körében ez az a kiejtési hiba, amelyet (ha egyszer a téves beidegződés létrejött) a legnehezebb korrigálni. A [ə] ugyanakkor kevesebb problémát okoz (bár a nyelvtanulók egy része ezt is „készségesen” helyettesíti a magyaros [ø]-vel), talán abból adódóan, hogy más, a magyarok által gyakran tanult idegen nyelvekből (angol, német) a tanulók döntő többsége már ismeri ezt a hangot, csupán a figyelmüket kell felhívni erre a hasonlóságra a nyelvtanulási folyamat kezdetén.

\subsubsection{Az alacsony nyelvállású magánhangzók}

A magyarban két ilyen hang van: [0, a: $]{ }^{41}$ míg a mandarin hangtanok hol két ([a, a]), hol három ([a, $\Lambda, a])$, sőt esetenként még több ilyen magánhangzót vesznek fel. ${ }^{42}$ A magyar nyelvtanulók a kínai [a]-t (illetve mind az [a]-t, mind pedig az $[\Lambda]-t)$ a magyar [a:]-val (illetve annak a magyarban egyébként nem létező rövid változatával) azonosítják - ez semelyik irányban nem okoz megértési problémát, hiszen nincs olyan másik fonéma a mandarinban, amellyel keveredhetne, legfeljebb esztétikai kérdés a pontos kiejtés megtanítása. A másik alsó nyelvállású kínai magánhangzó, az [a] esete némileg problémásabb (például 王 [way] 'király'): ezt tipikusan vagy ugyancsak a magyar [a:] rövid változataként, vagy magyar [0]-ként ejtik, ami ugyan még mindig csak ,csúnya" ejtésmód, de jobban feltünik, mint az [a], illetve $[\Lambda]$ helyettesítése.

41 A mai beszélt magyar köznyelvben az [0] kiejtése általában nyíltabbá válik: [D].
42 Duanmu 2007: 38-40. 


\subsubsection{A magánhangzó-hosszúság}

Egy fontos rendszerszintü különbség a magyar és a kínai között (amelyre fentebb már utaltunk) az, hogy a magyarban a magánhangzók hosszúsága kontrasztív tulajdonság (ld. például tör [tør] vs. tőr [tø:r]. A kínaiban viszont a hosszúságnak nincs fonémikus értéke, egy környezetfüggő másodlagos képzési tulajdonság: a magánhangzó akkor és csak akkor hosszú, ha hangsúlyos nyílt szótag végi monoftongus. Bár ez egy lényegesnek tűnő különbség, de inkább a magyarul tanuló kínaiak számára jelent kommunikációs problémát, mint a kínaiul tanuló magyaroknak. A magánhangzó-hosszúság magyarbeli kontrasztív volta okán ugyanis a magyarok helyesen érzékelik és reprodukálják a kínaiban az (allofonikus) hosszkülönbséget.

\subsubsection{Szótagkezdő magánhangzók ${ }^{43}$}

Az utolsó „egyedi hangtani különbség”, amelyre fel kívánjuk hívni a figyelmet, a kínai szótagéli felső nyelvállású magánhangzók kérdése azokban a szótagokban, ahol mind a szótagkezdeti mássalhangzós pozíció, mind a rímkezdő siklóhang pozíciója üres. A kínai magánhangzók artikulációja ugyanis jellemzően „simán” indul (lágy hangindítás: a gégefőnél a hangszalagok a levegő kiáramlásának megkezdésével egy időben zárulnak), míg a magyar magánhangzóké sok beszélő kiejtésében úgy, hogy a hangrés előbb zárul, mint a levegőáramlás kezdete (feszes hangindítás). ${ }^{44}$ Ez magyarázza, hogy a magyar nyelvtanulók a szótagkezdő magas nyelvállású magánhangzók előtt homorgán siklóhangokat érzékelnek, és így is reprodukálják ezeket a szótagokat, például efféle ,fantom” [j]-vel az olyan szótagokat, mint [i:] (yi 一 'egy'), [y:] (yu 鱼 'hal'): *[ji:] ill. *[jy:], és hasonlóan a hátul képzett [u] esetében: [ $\left.{ }^{\mathrm{w}} \mathrm{u}:\right]$ (wu 五 'öt') $\rightarrow$ *[wu:], sőt akár *[vu:]. A pinjin átírás éppenséggel „,rá is segít” erre a hibára azzal, hogy reprezentálja is e ,fantomhangokat”, a magánhangzó betüje elötti $y$-, illetve $w$ - betükkel. Mindazonáltal e probléma is inkább a kiejtés autenticitását érinti, mintsem az érthetőséget rontaná.

43 Köszönetünket fejezzük ki Deme Andreának (ELTE), akivel alaposan megvitattuk ezen rész tartamát. Az itt közöltek azonban nem reprezentálják az ő nézeteit ezekben a kérdésekben.

44 A hangindításbeli variációról ld. Gósy (2004)-et és Seikel et al. (2010)-et. 


\subsubsection{A magyar és a kínai összetett magánhangzós elemek összevető elemzése}

Mint már említettük, a mandarin kínaiban 13 összetett magánhangzó van: 9 diftongus és 4 triftongus. Szigorúan véve a magyarban nincsenek ilyen összetett magánhangzók, bár egyes jövevényszavakban azért találunk diftongusokat (vö. 3. 1j.). Az összetett magánhangzók egyetlen szótag részét képezik, nem oszlanak el több szótagba - ilyen magánhangzós részt találunk például a következő szavakban: 好 hăo 'jó' $\rightarrow$ ao [av], 有 yǒu 'van, birtokol' $\rightarrow$ ou [ov] vagy [əテ], 家 jiā 'család' $\rightarrow i a$ [ja:]. Ezzel szemben az egyszerü magánhangzókból álló szekvenciákban (például magyar tea [te.o]/[ te $\left.{ }^{\mathrm{j}} \mathrm{\rho}\right]$, piac [pi.ots]/[pi ${ }^{j}$ ts], diák [di.a:k]/[ dija:k], fiatal [fi.o.tol]/[ fijo.tol]) két vagy több magánhangzó áll egymás után, de külön-külön szótagokat alkotva: te-a, pi$a c, d i-a ́ k, f i-a$-tal. Ezek kiejtése is jellegzetesen eltér egymástól. Vegyük például a [i.o] szekvencia esetét: ebben mind az [i], mind pedig az [o] megőrzi teljes, szótagalkotó magánhangzónkénti tulajdonságait, és a két hang kiejtési időtartama kb. azonos. Ezzel szemben egy [ia]/[ja] összetett magánhangzó nem osztható fel két, önmagában is magánhangzónak számító komponensre, egyetlen szótagként ejtjük ki, időtartamuk pedig nem azonos: a [j] másodlagos, rövid és gyenge, az [a] elsődleges, hosszú és erős. Megjegyzendő, hogy az elsődleges és másodlagos tagok sorrendje szerint az összetett magánhangzókat három típusba sorolhatjuk: úgynevezett záruló diftongusok, nyíló diftongusok és nyíló-záruló triftongusok különböztethetők meg. A kínai vonatkozásában az alábbi táblázat foglalja össze a típusba sorolást:

\begin{tabular}{|c|c|c|c|}
\hline $\begin{array}{c}\text { Összetett } \\
\text { magánhangzóosztály }\end{array}$ & Elemek & Típus & Rövid magyarázat \\
\hline \multirow[t]{2}{*}{ diftongusok } & $\begin{array}{l}\text { ai [aj], ei [ej], ao } \\
{[\mathrm{av}], \text { ou [ov] }}\end{array}$ & $\begin{array}{l}\text { záruló } \\
\text { diftongus }\end{array}$ & $\begin{array}{l}\text { Az első V erős, } \\
\text { a második gyenge. }\end{array}$ \\
\hline & $\begin{array}{l}\text { ia [ja], ie [je], ua } \\
\text { [wa], uo [wo], } \\
\text { üe }[y \varepsilon]\end{array}$ & $\begin{array}{l}\text { nyíló } \\
\text { diftongus }\end{array}$ & $\begin{array}{l}\text { Az első } \mathrm{V} \text { gyenge, } \\
\text { a második erős. }\end{array}$ \\
\hline triftongusok & $\begin{array}{l}\text { iao [jav], iou } \\
\text { [jov], uai [waj], } \\
\text { uei [wej] }\end{array}$ & $\begin{array}{l}\text { nyíló- } \\
\text { záruló } \\
\text { triftongus }\end{array}$ & $\begin{array}{l}\text { A középső V az } \\
\text { elsődleges, elötte } \\
\text { és utána egyaránt } \\
\text { gyenge V-k. }\end{array}$ \\
\hline
\end{tabular}

12. táblázat. Összetett magánhangzók a mandarinban 
A magánhangzó-szekvenciák és az összetett magánhangzók különbségét pedig a 13. táblázat mutatja meg:

\begin{tabular}{|l|c|c|c|}
\hline \multicolumn{1}{|c|}{ Megnevezés } & A nyelv helyzete & Típus & Erősség \\
\hline $\begin{array}{l}\text { Magánhangzó- } \\
\text { szekvencia (magyar) }\end{array}$ & rögzült & $\underline{\mathrm{V}} \underline{\mathrm{V}}$ & \multirow{2}{*}{ egyenlő } \\
\hline \multirow{2}{*}{$\begin{array}{l}\text { Összetett } \\
\text { magánhangzó (kínai) }\end{array}$} & \multirow{2}{*}{ változó } & $\underline{\mathrm{V} \mathrm{V}}$ & \multirow{2}{*}{ különböző } \\
& & $\underline{\mathrm{V} \mathrm{V} \mathrm{V}}$ & \\
\hline
\end{tabular}

13. táblázat. Magánhangzó-szekvenciák és összetett magánhangzók

\subsection{Tónusok a mandarin kínaiban}

\subsubsection{A négy lexikális tónus}

Mielött rátérnénk a magyar és a kínai szótagszerkezet összevetésére, beszélnünk kell a lexikális tónusokról, a kínai (és számos más) nyelv jól ismert jellegzetességéről, amely a magyarból (illetve általában az európai nyelvekből) teljesen hiányzik. Aligha meglepő, hogy a tónusok felismerése és kiejtése jelentős nehézséget okoz a magyar anyanyelvü nyelvtanulóknak, csakúgy, mint mindenkinek, akinek az anyanyelvében nincs tónusrendszer (vagy éppenséggel van, de nem szótagalapú). Nem is annyira a tónusok természetének és szerepének tudatos ismerete szintjén mutatkoznak a nehézségek (a jelenség leírása és megértése nem túlságosan bonyolult feladat), hanem a beszédben való felismerésük, megértésük, valamint különösen a beszédben való helyes és automatikus produkciójuk az, ami nehezen sajátítható el. A szótag egészének tulajdonságaként tekintendő és jelentésmegkülönböztető erővel bíró (azaz fonémikus) tónusok elsődleges jellegzetessége a dallamkontúrjuk, de az időtartam és az intenzitás is szerepet játszik a percepciójukban. A standard mandarin kínaiban négy lexikális tónust lehet megkülönböztetni, ezek neve rendre: első (vagy yīnpíng 阴平 'sötét egyenletes'), második (vagy yángpíng 阳平 'világos egyenletes'), harmadik (vagy shăngshēng 上声 'emelkedö'), valamint negyedik (vagy qùshēng 去声 'elmenő'). Ezek mindegyikével kontrasztban áll 
továbbá a tónustalanság, azaz a lexikális tónus hiánya egy adott szótagon - az ilyen szótagokat gyakran semleges vagy könnyü tónusúnak is nevezik. ${ }^{45}$

A Chao-féle rendszer ${ }^{46}$ a következő módon ábrázolja e tónusok értékeit: a hangmagasságot a vertikális dimenzió reprezentálja 5 értékkel (ahol „1” jelöli a beszélő normális beszédbeli hangmagasság-tartományának legalsó, „,5” pedig a legfelső értékét; ,3” a középérték). A tónusokat az induló és a záró hangmagasság-értékükkel adjuk meg, illetve ha töréspont van a dallamkontúrban, akkor a töréspont értékét is kiírjuk. Eszerint a négy mandarin lexikális tónus így jellemezhető:

- 1. tónus (T1): magas szinttartó, Chao jelölési rendszerében: 55 (vagyis a kontúr a normál hangmagasság-tartomány legfelső magasságán indul, és végig ott is marad). A pinjin átírásban e tónus diakritikus jele a fömagánhangzó fölé helyezett ${ }^{-}$jel, például: $y \bar{i} n$.

- 2. tónus (T2): magas emelkedő, Chao rendszerében: 35 (tehát a tartomány középértékéről indul a dallam, és a tartomány tetejéig emelkedik). A pinjin átírásban diakritikus jele: ', például: yáng.

- 3. tónus (T3): ereszkedő-emelkedő (a hangmagasság-tartomány alsó részében), Chaónál: 214 (azaz a tartomány alja feletti első szintről indul lefelé, a tartomány aljának megfelelő magasságig, ahonnan viszont egy emelkedő szakasz következik, amely a tartomány középpontjánál némileg magasabbra ér). Diakritikus jele: ` , például: shăng.

- 4. tónus (T4): meredeken eső, Chao rendszerében: 51 (azaz a hangmagasság-tartomány tetejéről indulva gyorsan lesiklik a legmélyebb értékre). Pinjin-átírásbeli jele: ', például: qù .

45 Nem mindenki osztja azt a vélekedést, hogy az úgynevezett semleges vagy könnyü tónusú szótagok valóban tónustalanok, ezért egyes elemzések egy ötödik tónusértékként veszik azt fel. Anélkül, hogy az ilyen megközelítések melletti érvekkel foglalkoznánk, megelégszünk annak megállapításával, hogy a jelen tanulmány tárgya és céljai szempontjából egyszerübb tónustalanként katalogizálni az ilyen szótagokat. Részletekért ld. a 2.3.2. részt. 
A következő táblázat összefoglalva tartalmazza a négy lexikális tónust:

\begin{tabular}{|c|c|c|c|c|}
\hline Tónus & $\begin{array}{l}\text { Dallam- } \\
\text { kontúr }\end{array}$ & Leírás & $\begin{array}{l}\text { Diakri- } \\
\text { tikum }\end{array}$ & Példák \\
\hline $\begin{array}{l}\text { 1. tónus } \\
\text { T1 (yinping) }\end{array}$ & 55 & $\begin{array}{l}\text { magas } \\
\text { szinttartó }\end{array}$ & - & $\begin{array}{l}\text { 摸 } m \bar{o} \text { 'érint', } \\
\text { 星 } x \bar{i} n g \text { 'csillag' }\end{array}$ \\
\hline $\begin{array}{l}\text { 2. tónus } \\
\text { T2 (yángpíng) }\end{array}$ & 35 & $\begin{array}{l}\text { magas } \\
\text { emelkedő }\end{array}$ & , & $\begin{array}{l}\text { 桃 táo 'őszibarack', } \\
\text { 红 hóng 'piros' }\end{array}$ \\
\hline $\begin{array}{l}\text { 3. tónus } \\
\text { T3 (shăngshēng) }\end{array}$ & 214 & $\begin{array}{l}\text { ereszkedő- } \\
\text { emelkedő }\end{array}$ & $v$ & $\begin{array}{l}\text { 马 } m a ̆ \text { 'ló', } \\
\text { 水 } s h u \grave{~ ' v i ́ z ' ~}\end{array}$ \\
\hline $\begin{array}{l}\text { 4. tónus } \\
\text { T4 (qùshēng) }\end{array}$ & 51 & $\begin{array}{l}\text { meredeken } \\
\text { eső }\end{array}$ & 、 & $\begin{array}{l}\text { 坏 huài 'rossz', } \\
\text { 二 èr 'kettő' }\end{array}$ \\
\hline
\end{tabular}

14. táblázat. A mandarin kínai négy lexikális tónusértéke

A 2. ábra egy lehetséges grafikus megjelenítést mutat, négy (egymástól csak tónusértékükben különböző) morfémával: $m \bar{a}$ ('anya' 妈), $m a ́$ ('zsibbadt' 麻),

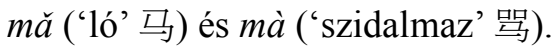

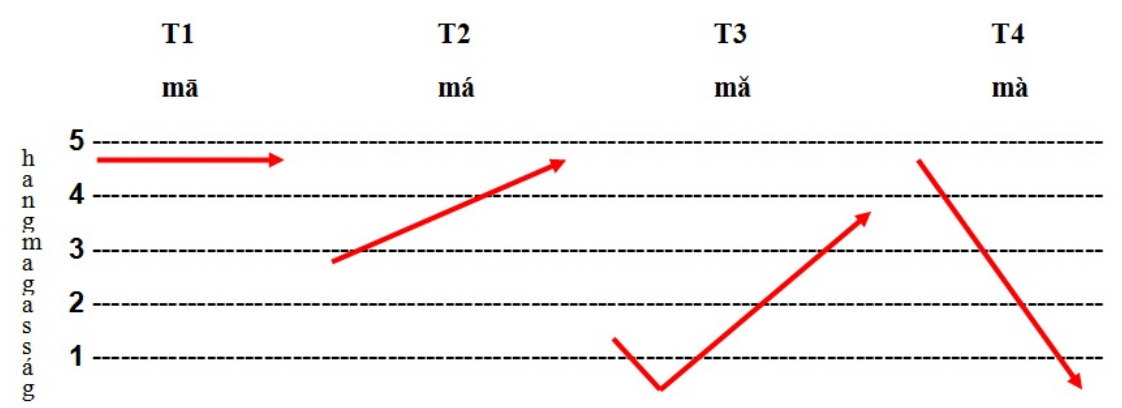

2. ábra. A négy tónus grafikus ábrázolása

\subsubsection{A „semleges” vagy „könnyü” tónus (qīngshēng)}

A hangtani leírásokban gyakorta találunk a fentebb tárgyalt négy lexikális tónus mellett egy ötödiket is, amelyet „semleges tónusként” vagy „könnyü tónusként" emlegetnek. Ennek önálló tónus volta azonban erősen vitatható - sokkal inkább a tónus (tónusérték) hiányáról kell beszélnünk az ilyen szótagokkal 
kapcsolatban. Huang és Liao ${ }^{47}$ is emellett érvel. Ilyen szótagok a beszédben nem állhatnak soha magukban, csak nagyobb, többtagú egységek (szavak, frázisok, tagmondatok) részeként fordulnak elö, és nincs lexikálisan meghatározott hangmagasság-értékük - ehelyett e szótagok enklitikumként viselkednek, így a megelőző szótag tonális kontúrjához illeszkedik az ejtésük. Mint Huang és Liao írják: „Általában véve, a 3. tónus (vagyis shăngshēng) után álló qīngshēng rendszerint viszonylag magas hangon lesz kiejtve (a tartomány 4. pontja magasságában), az 1. (yĩnpíng) vagy 2. (yángping) tónus után álló viszonylag mélyen (a skála 2., ill. 3. pontján), míg a 4. (qùshēng) tónus utáni a legmélyebb ponton (a skála 1. pontján). ${ }^{48}$ Huang és Liao fel is sorolja a morfémák azon jellegzetes kategóriáit, amelyekben qīngshēng fordul elő:

- strukturális és aspektuspartikulák (például 的 $d e$, 地 $d e$, 得 $d e$, 着 $z h e$, 了 $l e$, 过 $g u o$ ) és mondatvégi partikulák (például 吧 $b a$, 嘛 $m a$, 呢 $n e$, 啊 $a$ ),

- reduplikált egységek nem kezdő szótagjai (például 娃娃 wáwa, 弟弟 didi, 看看 kànkan, 玩玩 wánwan),

- (ál)szuffixumok (például 子 $z i$, 头 tou, 们 men),

- irányszavak (például 来 lai, 去 $q u$, 起来 qilai, 下来 xiàlai),

- a ge osztályozószó,

- fönevek és névmások utáni helyszavak (lokatívumok) (például 这里 zhèli, 路上 lùshang),

- egyes gyakori kéttagú szavak második szótagja (például 知道 zhīdao, 明白 mingbai). ${ }^{49}$

A tónustalanság világos oppozícióban áll a lexikális tónusspecifikáltsággal, azaz jelentésmegkülönböztetés alapja lehet. Például: 东西 dōngxī 'kelet és nyugat' vs. 东西 dōngxi (a második szótag qìngshēng)'dolog'.

A tónusok fontosságát (mind a percepció, mind a produkció oldalán) jól szemléltetik az azonos szegmentális tartalmú, de eltérő tónusú morfémák összevetései (mint például a fentebbi 2. ábra példái: $m \bar{a}$ 'anya' 妈, $m a ́$ 'zsibbadt' 麻, $m a \check{a}$ 'ló' 马 és $m a ̀$ 'szidalmaz' 骂, amelyekhez továbbá hozzávehető

Huang-Liao 1991: 195.

Huang-Liao $i . m$. E cikk szerzőinek fordítása.

49 Azon szavak tartoznak ide, amelyek hangsúlymintája „trochaikus” (azaz a második szótagjuk hangsúlytalan). A kínai nyelv kéttagú szavainak többsége ,jambikus” hangsúlyozású (Chao 1976). 
még a tónustalan $m a$ 吗 [eldöntendő kérdés mondatvégi partikulája]). ${ }^{50}$ Nagyszámú minimálpár van, amelyek tagjai csak tónusukban különböznek, például: măi huà 买画 'vesz-kép' $\rightarrow$ 'képet vesz' vs. mài hua 卖花 'elad-virág' $\rightarrow$ 'virágot elad'; dōngxi 东西 'dolog' vs. dōngxī 东西 'kelet (és) nyugat'; vagy jiéshù 结束 'befejez' vs. jiè shü 借书 'könyvet kölcsönöz'.

\subsubsection{Tónusmoduláló szabályok (sandhi; biàndiào 变调)}

Mint láttuk, a standard kínai nyelvváltozatban négy lexikális tónus van. Ám több szótagból álló prozódiai egységekben (szavak, frázisok, mondatok) az egyes szótagokhoz társított tónusok egymás hatása alatt megváltoztathatják jellegüket, dallamukat - ezt a jelenséget tónusmodulációnak (tónussandhinak) nevezzük, és két fő típusát különböztethetjük meg: a fonémikus és a szubfonémikus tónusmodulációt. Az előbbi esetben valamely lexikális tónus hangértéke egy másik önállóan létező lexikális tónus értékére változik a környezet függvényében, míg az utóbbi esetben egy tonális hangérték úgy módosul, hogy egy önállóan, lexikálisan nem létező érték jön létre. A fonémikus modulációnak van kötelező és fakultatív altípusa. Az elöbbire példa a „T3 $\rightarrow \mathrm{T} 2$ ” tónusváltás: két, azonos prozódiai egységbe eső harmadik tónus (azaz shăngshēng) közül az előbbi a második tónus (azaz yángping) hangértékére módosul; pél-

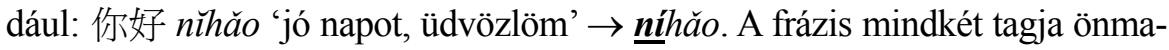
gában T3 lexikális tónusú, de a frázist egyben, egyetlen prozódiai szóként kiejtve az első tag T3 értéke T2-vé válik, azaz egy másik tónusfonéma (tonéma) jellegzetes hangértékét veszi fel. A fakultatív tónusváltó szabályok közé tartozik például:

- $\mathrm{T} 2 \rightarrow \mathrm{T} 1 /\left[\{\mathrm{T} 1 / \mathrm{T} 2\}_{\_} \mathrm{Tx}\right]_{\pi}$, azaz: három szótagú egységek középső szótagjában a yángping tónus yinnpingre módosul, ha a megelőző szótag tónusa magasan ér véget, például: 还没有 lexikálisan: háiméíyǒu $\rightarrow$ felszínen: háimê̄iyǒu

50 Meg kell ugyanakkor jegyeznünk, hogy még a tónusokkal együtt is igen nagy a morfémikus homofónia aránya a mandarinban, azaz minden lehetséges szótaghoz (ua. szegmentális anyaggal ÉS ua. tónussal rendelkező) számos morfémát lehet társítani (egyes szótagokhoz több tucatnyit [!]). 
Más esetekben a tónusmoduláció kötelezően megy végbe, de csak bizonyos lexémák érintettek a szabályban - ilyen a 一 ȳ 'egy' és a 不 bù 'nem' lexémák esete, amikor egyetlen frázison belül (például $\mathrm{Num}+\mathrm{Cl}$, illetve $\mathrm{Neg}+\mathrm{V}$ ) az utánuk álló bizonyos tónusú szótag hatására a lexikális tónusértékük megváltozik:

- T4 $\rightarrow \mathrm{T} 2$ / [ $\left.\_\mathrm{T} 4\right]_{\pi}$, de csak az alábbi lexémában: 不 bù 'nem';

- $\mathrm{T} 1 \rightarrow \mathrm{T} 2 /\left[{ }_{-} \mathrm{T} 4\right]_{\pi}$, de csak az alábbi lexémában: — yi 'egy';

- $\mathrm{T} 1 \rightarrow \mathrm{T} 4 /\left[{ }_{\ldots} \mathrm{T} 1 / \mathrm{T} 2 / \mathrm{T} 3\right]_{\pi}$, de csak az alábbi lexémában: 一 ȳ̇ 'egy'

A szubfonémikus modulációnak (amely mindig kötelezö érvényü) egy tipikus példája a harmadik tónus (shăngshēng) „feleződése” egy frázison belüli nem hármas tónusú szótag előtt, amikor az alapdallamnak csak a kezdő, ereszkedő szakasza marad meg:

$-214 \rightarrow 21 /\left[{ }_{-} \mathrm{T} 1 / \mathrm{T} 2 / \mathrm{T} 4\right]_{\pi}$

Ugyancsak szubfonémikus módosulás éri az együtt ejtett két négyes tónusú (qùshēng) közül az elsőt:

$-55 \rightarrow 53 /\left[{ }_{-} \mathrm{T} 4\right]_{\pi}$

\subsection{A magyar és a kínai szótagszerkezet kontrasztív elemzése}

\subsubsection{Szótagszerkezet a magyarban és a kínaiban}

A szótag a hangrendszer fontos alapegysége. Egy vagy több fonéma szekvenciája szótagot alkot. Egy magyar szó több szótagból állhat, és mindegyik szótagban van egy magánhangzó. Más szóval, egy szó szótagjainak számát a magánhangzóinak száma határozza meg. Az olyan szótagokat, amelyek magánhangzókra végződnek, nyílt szótagoknak nevezzük, ilyenekből áll például a ceruza és a zene szó. A mássalhangzóra végződő szótagokat pedig zárt szótagoknak nevezzük, ilyenekből áll például az altat vagy a botlás szó. Egy szótag állhat egyetlen magánhangzóból is, egy magánhangzóból és egy mássalhangzóból vagy egy magánhangzóból és több mássalhangzóból.

A magyar nyelvben a szótag felépítése 'szótagkezdet + szótagmag + szótagzárlat'. A szótagkezdet és a szótagzárlat egyike sem kötelező elem, lehetséges, hogy a szó magánhangzóval kezdődik és/vagy arra végződik. 
A szótagkezdet és a szótagzárlat lehet összetett (több mássalhangzóból álló), ettől a komplexitástól eltekintve a magyar szótagok a következő struktúrájúak lehetnek:

\begin{tabular}{|c|c|c|c|}
\hline & Szó elején & Szó belsejében & Szó végén \\
\hline $\mathbf{C V}$ & $\begin{array}{l}\text { ce.ru.za } \\
\text { Kí.na }\end{array}$ & $\begin{array}{l}\text { fe.ke.te } \\
\text { vi.lá.gos }\end{array}$ & $\begin{array}{l}\text { ka.to.na } \\
\text { sző.lö }\end{array}$ \\
\hline V & $\begin{array}{l}\text { a.pa } \\
\text { í.ró }\end{array}$ & $\begin{array}{l}\text { fi.a.tal } \\
\text { i.di.ó.ta }\end{array}$ & $\begin{array}{l}\text { szi.a } \\
\text { rá.di.ó }\end{array}$ \\
\hline VC & $\begin{array}{l}\text { asz.tal } \\
\text { ár.pa }\end{array}$ & $\begin{array}{l}\text { a.or.ta } \\
\text { ki.ál.tás }\end{array}$ & $\begin{array}{l}\text { fi.al } \\
\text { di.ák }\end{array}$ \\
\hline CVC & $\begin{array}{l}\text { lec.ke } \\
\text { lám.pa }\end{array}$ & $\begin{array}{l}\text { ke.men.ce } \\
\text { ta.nár.nö }\end{array}$ & $\begin{array}{l}\text { ti.los } \\
\text { kí.ván }\end{array}$ \\
\hline
\end{tabular}

15. táblázat. Szótagszerkezeti mintázatok a magyarban

A fentiekből világos, hogy a magyar nyelvben: (1) a szó elején, közepén és végén is bármilyen szótag állhat; (2) a szavakban a hosszú és a rövid szótagok eloszlása azonos; (3) sem a nyílt, sem a zárt szótagok nem korlátozódnak a szó végére. A fenti példákban szereplő szavak mind több szótagúak, de a magyar nyelvben vannak természetesen egy szótagú szavak (például: $i r$, jó, nap, ó). A szótagok kezdetében és zárlatában előfordulhat két vagy három mássalhangzó együttese is (például kvarc, prém, sztrájk, spricc, illetve test, park, tett, karszt).

A mandarin kínai nyelv monoszillabikus, vagyis a morfémák döntő többsége egy szótagú. A szótag a hagyományos kínai felosztás szerint (ami elsőre nagyon hasonlónak tünik a kurrens nemzetközi fonológiai szakirodalomban használt „kezdet + rím” felosztáshoz, ám valójában a két elemzés viszonya bonyolult ${ }^{51}$ ) kezdetre (声母), rímre (韵母) és tónusra (声调) oszlik. A kezdet egy szótageleji mássalhangzó lehet. Például a普通话 pǔ.tōng.huà szó három szótagjának kezdetei rendre a $\left[\mathrm{p}^{\mathrm{h}}\right],\left[\mathrm{t}^{\mathrm{h}}\right]$, illetve $[\chi]$ mássalhangzók. A mandarin nyelv 22 mássalhangzója a [y] kivételével (amely csak a rím végi pozícióban jelenhet meg, például 听 tīng [ $\mathrm{t}^{\mathrm{h}}$ in] 'hallgat', 中 zhōng [ț̦uy] 'közép') mind előfordulhat kezdetként, vagyis 21 szótagkezdő mássalhangzóról beszélhetünk. Azokat a szótagokat, amelyek kezdetében nem találjuk meg ezek egyikét sem,

51 Ld. erről például Zhu (2018: 302 skk.) és Lin (2007: 108 skk.) diszkusszióját. 
azaz csak rímből állnak, ,zéró kezdetü” szótagnak nevezzük. ${ }^{52}$ Ilyenek például: 爱 ài [aj] 'szeret' vagy: 儿 ér [ə’] 'fiúgyermek'. Megjegyzendő, hogy a pinjin átírásban $y$-nal vagy $w$-vel kezdődő szótagok is ilyen ,zéró kezdetü” szótagok (például 一yı [ii] 'egy', 五 wǔ ["w:] 'öt', vagy 要 yào [jav] 'akar, fog'), vagyis ezek a betük nem mássalhangzók (például approximánsok) jelei, hanem rímkezdő siklóhangot (vagy esetleg a főmagánhangzó „lágy indítását”, vö. 2.2.3.) jelölik.

A rím a szótagnak a szótagkezdetet követő szegmentális része (vagyis a tónus nélkül tekintjük). A rím lehet egyetlen magánhangzó vagy egy összetett hangzó (di- vagy triftongus) - e két esetet illusztrálja például a 书包 shū.bāo 'aktatáska' szó: az első szótagban csak egy egyszerủ magánhangzó van: [u:], míg a másodikban egy diftongus: [av]. Más esetekben a rím egy záró mássalhangzóra végződik, mint például a 冬天 dōngtiān [dơn.t. ${ }^{\mathrm{h}} \mathrm{j} \varepsilon n$ ] 'tél' szó két szótagja, amelyek (rendre) a [n], illetve a [n] hangzókkal zárulnak. A mandarin szótagstruktúra alapvető eseteit tehát az alábbi táblázatban foglalhatjuk össze:

\begin{tabular}{|c|l|c|l|}
\hline $\begin{array}{c}\text { Szótagstruktúra- } \\
\text { típusok }\end{array}$ & Példák & $\begin{array}{c}\text { Szótagstruktúra- } \\
\text { típusok }\end{array}$ & \multicolumn{1}{|c|}{ Példák } \\
\hline CV & 妈 mā 米 mǐ & V & 啊 a 哦 o \\
\hline CGV & 下 xià 略 lüè & VG & 爱 ài 傲 ào \\
\hline CVG & 白 bái 飞 fēi & GV & 我 wǒ 月 yuè \\
\hline CGVG & 快 kuài 票 piào & GVG & 有 yǒu 外 wài \\
\hline CVC & 看 kàn 很 hěn & VC & 暗 àn 昂 áng \\
\hline CGVC & 脸 liăn 穷 qióng & GVC & 远 yuăn 问 wèn \\
\hline
\end{tabular}

16. táblázat. Szótagszerkezeti mintázatok a mandarin kínaiban

52 Hogy az ilyen szótagkezdet üres-e, vagy elfoglalja valamiféle „null” mássalhangzó, az nem triviális kérdés, amelynek tárgyalására itt nem térünk ki; az érdeklődőknek javasoljuk Duanmu (2007: 81 skk.) elemzését erről. 


\subsubsection{A magyar és a kínai szótagszerkezet kontrasztív elemzése}

A fenti tárgyalás alapján az alábbi összevető táblázatot állíthatjuk össze, a lehetséges szótagtípusokról:

\begin{tabular}{|l|l|c|}
\hline Nyelv & Mássalhangzók és magánhangzók eloszlása & Tónus \\
\hline magyar & $\mathrm{C}^{*} \mathrm{~V}, \mathrm{~V}, \mathrm{VC} *, \mathrm{C}^{*} \mathrm{VC}^{*}$ & - \\
\hline kínai & $\begin{array}{l}\mathrm{CV}, \mathrm{CVG}, \mathrm{CGV}, \mathrm{CGVG}, \mathrm{CVC}, \mathrm{CGVC}, \\
\mathrm{V}, \mathrm{VG}, \mathrm{GV}, \mathrm{GVG}, \mathrm{VC}, \mathrm{GVC}\end{array}$ & + \\
\hline
\end{tabular}

17. táblázat. Lehetséges szótagtípusok a magyarban és a mandarin kinaiban

A lényegi hasonlóságok az alábbiakban foglalhatók össze:

1. Mindkét nyelvben van magánhangzóval kezdődő szótag.

2. Mindkét nyelvben vannak nyílt és zárt szótagok.

3. Van átfedés a lehetséges szegmentális mintázatokban a két nyelv közt: $\mathrm{CV}, \mathrm{V}, \mathrm{VC}, \mathrm{CVC}$ (de a kínaiban nincs komplex kezdet/zárlat, és a zárlati mássalhangzók köre roppantul korlátozott).

4. A magánhangzó kötelező eleme a szótagnak mindkét nyelvben. ${ }^{53}$

A lényegi különbségek pedig az alábbiak:

1. A kínai tonális nyelv, a magyar nem - ami egy igen nyilvánvaló és szembeötlő eltérés. Minden kínai szótag rendelkezik tónusspecifikációval (még ha adott esetben ez egy negatív specifikáció, azaz tónushiány is, ld. 2.3.2.).

2. A magyar megenged mássalhangzó-torlódást mind a szótagkezdetben, mind a zárlatban, míg a kínai nem.

3. A fentivel szoros összefüggésben a kínai szótag maximálisan négy szegmentális fonémából állhat (CGVG, CGVC), addig a magyarban akár hat szegmentum is lehet egyetlen szótagban (például sztrájk [stra(:)jk] CCCVCC).

53 Bár mindkét nyelvben vannak olyan indulatszók, amelyekre ez nem áll, de ezekre általában a nyelvekben lazább fonotaktikai megszorítások vonatkoznak (Jespersen 1924: 90; Ameka 1992). Továbbá a mandarinban az itt magánhangzóként elemzett [1], illetve [ح] hangokat egyes elemzések szillabikus mássalhangzónak ([z], illetve [z]) tartják, például Duanmu (2007: 34-35). 
Szótagszerkezet terén tehát a magyar lényegesen bonyolultabb, vagyis e téren a kínaiul tanuló magyarok helyzete lényegesen könnyebb, mint a magyarul tanuló kínaiaké, akiknek komoly nehézséget okoznak a komplex kezdetek és zárlatok a magyarban.

\subsection{Hangsúly és intonáció}

\subsubsection{Hangsúly a magyarban és a kínaiban}

A (nyomaték)hangsúly lényegében egy szegmentumsorra (szótagra) eső hangerőtöbblet, amelyet nagyobb fiziológiai erővel hozunk létre, és a hangképzésben részt vevő izmok fokozottabb müködésével. Akusztikailag tipikusan hangerö-növekedésként és/vagy hangmagasság-emelkedésként valósul meg. A legtöbb nyelvben legalább kétféle hangsúlyt különböztetnek meg: szóhangsúlyt (amely lexikális tulajdonsága az adott szónak) és mondathangsúlyt (vagy prozódiai hangsúlyt), amely (tag)mondatszintü egységekben egyes elemeken az információstruktúra függvényében (például fókuszálás) jelenik meg. Minden több szótagú szónak sajátos lexikális hangsúlymintázata lehet, míg a mondatrészek közül az információstrukturális tulajdonságok alapján emelhetünk ki egyeseket megnövelt hangsúllyal.

A magyar szóhangsúlyról Siptár és Törkenczyezt írja: ${ }^{54}$ „szótári alakjában a magyar szavaknak tipikusan egyetlen elsődleges hangsúlyuk van, mely az első szótagra esik, akár egyszerü szóról (pl. ịskola), akár képzett szóról (pl. forrósodik), akár pedig összetett szóról (pl. szénanátha) legyen is szó."

A hangsúlytalanodásnak (vagyis a lexikális hangsúly elvesztésének) ugyanakkor két alesete van: a spontán kliticizálódás és a hangsúlyirtás, amelyeket Kálmán és Nádasdy az alábbi példákkal illusztrál: ${ }^{55}$

(1) a) 'Géza 'táncolni akar. (vö.: ?? 'Géza 'akar 'táncolni.)

b) 'Géza 'táncolni akar a 'magas 'fekete 'lánnyal.

c) 'Géza bácsi

d) 'Géza bácsi 'táncolni akar a 'magas 'fekete 'lánnyal.

54 Siptár-Törkenczy 2000: 21. E cikk szerzőinek fordítása.

55 Kálmán-Nádasdy 1994. 
(2) a) 'Jenő 'táncolni imád.

(vö. 'Jenő 'imád (')táncolni.)

b) 'Jenő 'táncolni imád a magas fekete lánnyal.

c) 'Jenő 'táncolni akar.

d) 'Jenő 'táncolni akar a magas fekete lánnyal.

(1)-ben a kurzivált akar, bácsi szavak jobbról hozzásimulnak (kliticizálódnak) a megelőző szóhoz, miáltal egyetlen hangsúlytartományt alkotnak vele. Ennek oka e szavak (lexikális tulajdonságukként regisztrált) hangsúlykerülő volta. A (2) példasorban más jelenséget látunk: mivel az imád szó nem hangsúlykerülö, így a (2a)-beli hangsúlymintázat csak akkor és úgy állhat elö, ha a táncolni szó emfázist visel (fókuszhangsúly), amelynek egyik kísérőjelensége az ugyanazon a prozódiai tartományon belül mögötte álló szavakat érintő hangsúlyirtás. A (2b) példán jól látszik, hogy az ,imád a magas fekete lánnyal” szósor minden egyes tagja elveszt(het)i lexikális hangsúlyát ilyen helyzetben. $(2 \mathrm{c}, \mathrm{d})$ pedig $(1 \mathrm{a}, \mathrm{b})$-vel vetendő össze: az utóbbi esetben szintén hangsúlyirtás történik a fókuszos táncolni szó utáni zónában. Mint Siptár és Törkenczy írják: ${ }^{56}$,az irtóhangsúlyról két fontos tény, hogy nem szükségszerüen erősebb, mint a nem-irtó jellegü hangsúly, és hogy nem követheti további hangsúly egyazon mondaton belül, kivéve ha az egy újabb irtóhangsúly. Az irtóhangsúlyt nem tartalmazó mondatok prozódiája lapos, és semleges értelmezésnek felel meg; az irtóhangsúlyos prozódiájú mondat ugyanakkor kontrasztív vagy emfatikus értelmezésü."

A kínai, mint láttuk, tonális nyelv. A tonalitás (mint alapfrekvencia-jelenség) olyannyira elsődleges és élesen megkülönböztethető tulajdonsága a kínainak, hogy emiatt gyakran vélik úgy róla, hogy nincs is hangsúly- és intonációs rendszere. Ahogy például Norman írja: ${ }^{57}$ „Egyesek [...] nyilvánvalóan úgy vélik, hogy a hangmagasság nem játszat szerepet egyszerre lexikális szinten (tónus) és mondatszinten (intonáció).” Ez azonban, mint Norma rámutat, egyáltalán nincs így: „Valójában a tónusok mellett a standard kínai nyelvben van hangsúly és intonáció is."

A kínai szavak hangsúlymintázatát meghatározó szabályok viszonylag egyértelműek. Mint Luo és Wang írják: ,két szótagú szavakban az elsődleges

\footnotetext{
56 Siptár-Törkenczy 2000: 21. E cikk szerzőinek fordítása.

57 Norman 1988: 148. E cikk szerzőinek fordítása.

58 Uo.
} 
hangsúly a második szótagra esik, míg az első szótag viszonylag hangsúlytalan, kivéve azon eseteket, amelyekben a második szótag semleges tónusú" ${ }^{59}$

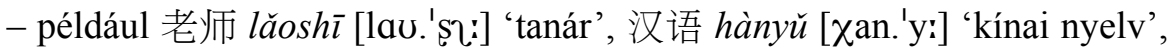
中国 zhōngguó [tșun.'g̊no:] 'Kína'. Luo és Wang kijelentését kiterjesztve Lu továbbá ezt írja: ,ami a három és több szótagból álló kínai szavakat és frázisokat illeti, a főhangsúly az utolsó szótagon van." ${ }^{, 00}$ Ilyenek például: 普通话 pǔtōnghuà '[kínai] köznyelv', 语言教师 yǔyán jiàoshī 'nyelvtanár', 中华人民共和国 zhōnghuá rénmín gònghéguó 'Kínai Népköztársaság'. A semleges tónusra végződő ilyen egységek persze itt is kivételek, mert a föhangsúlyuk arra a teljes tónusértékkel bíró szótagra esik, amely balról legközelebb áll a szóvégi tónustalan szótaghoz, például: 妈妈 $\underline{\boldsymbol{m} \overline{\boldsymbol{a}}} m a$ 'anya', 你好吗 nǐ hăo ma 'jól vagy?', and 非常喜欢 fêicháng xĭhuan 'nagyon szeret'.

Ez a fajta föhangsúly a lexikai szinten van kijelölve, és a mondathangsúly megjelenési lehetőségei is ezekre a szótagokra esnek. Az persze, hogy esik-e rájuk mondathangsúly, a mondat szerkezetén és jelentésén múlik. Minél kiemeltebb szerkezetileg vagy értelmileg egy adott szó vagy mondatösszetevő, annál erösebb rajta a mondathangsúly. A magyarban a tartalmas szavak (fönevek, melléknevek, főigék, határozószók, mutató- és kérdőnévmások) jellemzően hangsúlyosabbak, míg például a segédigék, kötőszavak, névelők jellemzően hangsúlytalanok. Ez a kínaiban is hasonlóan müködik: ott is a tartalmas szavak rendelkeznek alaphangsúllyal, míg a funkciószavak sosem (vagy csak igen ritkán). ${ }^{61}$

\subsubsection{Intonáció a magyarban és a kínaiban}

Az intonáció a beszélt nyelv egyik alapvető fontosságú eleme. Számos különféle meghatározása született már, amelyek érintik a hangmagasság, a hangerö, a hangsúly és a ritmus fogalmait. Mi itt most a jelen céljainkra egy egyszerü(sítő) definícióval élünk: a beszélőnek a beszéde közbeni azon hangmagasság-változásainak sorát értjük alatta, amelynek jellegzetes mintázatai frázisnyi vagy (tag)mondatnyi beszédterjedelmen azonosíthatók - megkülönböztetendő a tónustól (amely szótagnyi szakaszokon érvényesül).

59 Luo-Wang 2002: 156-157.

60 Lu 2010: 3 .

61 Ez alól természetesen (mint talán minden nyelvben) kivételt képez a korrektív (helyesbítő) hangsúly és a metalingvisztikai használat. 
Az intonáció különféle jelentések, beszélői szándékok és attitüdök fontos kifejező eleme. Egyazon mondatnyi szósor különféle intonációs dallamokkal különböző üzeneteket hordozhat. A magyar intonáció legalapvetőbb funkciója a mondattípusok (kijelentés, eldöntendő kérdés, felkiáltás) elkülönítő megjelölése. A főhangsúlyos szótaggal induló szótagsoron megjelenő úgynevezett karakterdallamokat Varga öt csoportra osztva tárgyalja, és 11 karakterdallamot azonosít. $^{62}$ Az eső jellegü dallamok a kijelentésekre és a kérdőnévmásos kérdésekre jellemzők. A lebegő-eső dallamok az eldöntendő kérdések jelölői, míg az ereszkedő dallam a felkiáltásoké. A karakterdallamok előtti mondatszakaszon (jellegzetesen alacsony vagy magas szinttartó) elődallam, a karakter utáni, de azzal még egy megnyilatkozásban lévő szakaszon pedig (általában mély szinttartó) függelékdallam jelenhet meg.

A kínai intonációs dallamoknak két fő típusát szokták megjelölni: esőt és emelkedőt. A dallam hangfekvése tekintetében He Yang és Jin Song magas, viszonylag mély és mély intonációkat különböztet meg. ${ }^{63}$ A konkrét dallamminták (és általában az intonáció jelentősége) vonatkozásában azonban igen eltérő nézetek láttak napvilágot a szakirodalomban. A kommentek dallamát illetően Chao Yuen Ren például nem kevesebb, mint negyven (!) típust különített el ${ }^{64} \mathrm{Hu}$ Mingyang nyolcféle dallamról ír a mondatzáró karakter szerint, funkcióikhoz kötötten: állítások, kérdések, parancsok, felszólítások, döbbenetkifejező felkiáltások, sóhajok, megszólítások és folytatás-előkészítő szünetek. ${ }^{65}$ Ugyancsak funkcionális megközelítésben Shen Jiong megkülönböztet funkcionális intonációt és kommentártónus-intonációt. ${ }^{66}$ Lin Maocan pedig amellett érvel, hogy a kínai intonáció kétváltozós: hangmagasság- és határtónus-alapú. Véleménye szerint a kérdések és az állítások közötti különbségtételben a határtónusok játszanak fószerepet. ${ }^{67}$

A kínai nyelvben tehát a hanglejtés kérdése nem egyszerü. Ugyanúgy alapvető szerepet játszik benne az eső és emelkedő dallamok különbsége, mint más nyelvekben, de a konkrét müködésük leírása ma is viták tárgya. Ami pedig még bonyolultabbá teszi a problémát, az a (szótagokhoz rendelt) lexikális tónusok léte, hiszen azok is hangmagasság-változási minták, csakúgy, mint az into-

\footnotetext{
Varga 1994.

He-Jin 1992.

Chao 1929.

Hu 1987.

Shen 1994.

Lin 2004.
} 
náció. E két kategória viszonya mindig heves nyelvészeti viták tárgya volt. A talán legáltalánosabban elfogadott nézet szerint ${ }^{68}$ az intonációs dallamok a tónusdallamok szekvenciájára rátelepedve modulálják azokat, tehát például az emelkedő jellegü kérdő intonáció (mint dallamvonulat) megemeli az egész megnyilatkozás hangmagasságát, így azon belül konkrétan az összes benne foglalt tónusét (míg ugyanakkor az egyes tónusok relatív magasságértékei megmaradnak). Egy másik nagy hatású elmélet szerint, ${ }^{69}$ amely a „kis hullám” és a „nagy hullám” metaforákat használja a tónus és az intonáció megragadására, a „kis hullám” és a „nagy hullám” összegeként írható le a tónusok és a rájuk telepedő intonáció jelensége. Ezt pontosítva Wu Zongji az „„öszeget” mint a regisztereknek, azaz a tónus átlagos hangmagasságának és az intonáció átlagos hangmagasságának összegét határozza meg. ${ }^{70}$

Míg tehát tónus és intonáció egymástól független fogalmak az absztrakt szerkezeti (elemzési) szinten, addig a konkrét fizikai valóságban igen szorosan összefüggenek, egymástól el nem választhatók. Míg egy teljes megnyilatkozás kiejtésében az egyes tónusok inherens értékei lényegében megőrződnek, a tényleges kiejtési hangmagasságot (vagyis az alapfrekvencia-értékek) és a tónusdallamokat erősen befolyásolja az intonáció dallamvonulata.

Az intonáció jelentési értékét és fontosságát jól illusztrálja a következő példa: a 今天是你的生日 Jintiān shì nŭ de shēngrì 'Ma a te születésnapod van' és 今天是你的生日? Jintiān shì nĭ de shēngrì? 'Ma a te születésnapod van?’ mondatpár tagjai pontosan ugyanabból a szósorból állnak, amelynek minden egyes szótagja ugyanazt a tónusértéket viseli a két mondatban. Ugyanakkor az intonációs dallamuk jellegzetesen különböző: a kérdő funkciót speciális dallam képviseli - ez és csak ez különbözteti meg a két mondat kiejtett alakját. Ilyen példákat pedig bőséggel lehetne még hozni.

\section{Kontrasztív elemzés és a nyelvtanulás nehézségei}

Cikkünk zárásaként áttekintjük a fenti összevető elemzések pedagógiai implikációit, elsősorban abból a szemszögből, hogy a részletezett hangtani különbségek milyen mértékü odafigyelést igényelnek a nyelvtanároktól és

\footnotetext{
68 Például Shen 1989; He-Jin 1992.

69

Chao 1983.

Wu 1997.
} 
a nyelvtanulóktól. Egy lehetőség ennek felmérésére Prator kategorizációja, amely a kontrasztív elemzés pedagógiai értékébe vetett mély hiten alapul, és aszerint rangsorolja a nyelvek közti különbségek típusait, hogy azok várhatóan mekkora nehézséget okoznak L1 nyelv beszélói számára L2 nyelv tanulása során. Prator konkrétan 6 szintet különböztet meg, 0 -val jelölve a legkevésbé problémás, 5-tel pedig a legproblémásabb kategóriát. ${ }^{71}$

\begin{tabular}{|c|l|l|}
\hline Szint & Kategória & \multicolumn{1}{|c|}{ Magyarázat } \\
\hline 5 & felbontás & L1 egy elemének L2-ben két vagy több elem felel meg \\
\hline 4 & újdonság & L1-ből hiányzik az L2-ben jelen levő elem \\
\hline 3 & újrakódolás & L1 egy eleme új formában van jelen L2-ben \\
\hline 2 & hiány & L1 egy eleme hiányzik L2-böl \\
\hline 1 & összeolvadás & L1 két vagy több eleme L2-ben egy elemmé olvad össze \\
\hline 0 & azonosság & L1 és L2 megfelelő elemei azonosak \\
\hline
\end{tabular}

18. táblázat. Nehézségi szintek osztályozása Prator (1967) alapján

Az azonosság esetét, vagyis amikor nincs érdemi különbség az egymásnak megfeleltethető kategóriák között a két nyelvben, ezért gyakorlatilag nincs problémát okozó tényező a nyelvtanuló számára, „0” szintünek tekintjük, míg a felbontás esetét, amikor is L1 valamilyen kategóriája két (vagy több) különböző kategóriára képeződik le L2-ben, a legmagasabb rangú problématényezőnek (,5”) vesszük. Nyilvánvalóan nem mindegy egy adott nyelvpár esetén, hogy melyik az anyanyelv (L1), és melyik a célnyelv (L2), hiszen ami egyik irányban felbontás, az a másik irányban összeolvadás, vagyis egyazon jelenség lehet nagyon problémás a kínaiul tanuló magyarok számára, míg ugyanez jóval könnyebben kezelhető a magyarul tanuló kínaiak részére. Arról se feledkezzünk meg, hogy (azon túl, hogy ez alapvetően is egy, bár empirikus megfigyeléseken alapuló, de mégiscsak önkényes rangsorolás) a rangsor egyszerü sorba rendezés, nem arányskála - az újdonság esete (,4”) tehát egyértelmüen nagyobb problémát jelent (várakozásunk szerint) a nyelvtanuló számára, mint a hiány (,2"), de nem indikálja a skála, hogy a nehézség kétszer akkora lenne.

71 Prator 1967. 
Végül pedig azt is tartsuk szem elött, hogy a nyelvtanuló számára különféle beszédhangok azonosításának és/vagy produkciójának nehézsége nem feltétlenül arányos azzal a problémával, amit a hozzájuk kötődő nehézség a megértés-megértetés frontján okoz neki. Ha például olyan jelenségröl van szó, amely a megértést nem befolyásolja, akkor az érzékelés és/vagy a produkció nehézsége inkább „esztétikai”, mintsem kommunikációs problémát jelent.

Mivel a 0,1 és 2 kategóriájú helyzetek kevésbé valószínü (illetve gyakori) okai a kiejtési problémáknak, ezért a fentebb azonosított kontrasztok közül azokra koncentrálunk az alábbiakban, amelyek a 3-5 zónába esnek, akár percepciós, akár produkciós oldalon.

\subsection{Felbontás}

\section{Magánhangzók:}

- A magyar [i] és a kínai [i, 1, 2 ] hangok kontrasztja: a magyar tanulóknak nem okoz jelentős problémát a különbség felismerése, és bár alapvetően tisztában vannak azzal, hogy milyen hangokat kéne produkálniuk, az artikulációval nehézségeik adódnak. Ez gyakran eredményez „furcsa” hangzású elemeket, de csak elvétve vezet félreértéshez vagy megértési gondhoz.

- A magyar $[a(:)]$ és a kínai $[a, \Lambda]$ kontrasztja: a magyar tanulók általában nehezen tesznek ezek között különbséget, már a percepció szintjén is, de mivel a különbség a kínaiban itt sem fonémikus, és nem is különösebben éles, ezért itt sem jellemzőek a megértési nehézségek.

- A magyar [u] és a kínai [u, $\mathrm{u}]$ kontrasztja: csakúgy, mint az előzőnél, a magyarok számára nehézséget jelent a megkülönböztetés, de mivel e két hang a mandarinban nem áll oppozícióban, ezért ismét nem jelentös a funkcionális probléma.

\section{Mássalhangzók:}

- A magyar zöngétlen zárak/affrikáták vs. a mandarin aspirált-aspirálatlan (egyaránt zöngétlen) párok: a kínaibeli oppozíció „lekövetése” nem okoz nehézséget, sem a percepció, sem a produkció terén, vélhetően az artikulációs különbség nyilvánvaló volta okán. 


\section{2. Újdonság}

\section{Magánhangzók:}

- A mandarin $[\gamma]$ hang egyrészt jelentős produkciós nehézséget jelent a magyar tanulók számára, másrészt nehezen különböztetik meg a [ə]-tól. Mindemellett rendkívül nehéz elejét venni annak, hogy a magyarban meglevő [œ]-vel (vagy esetleg [ø]-vel) helyettesítsék. Mivel azonban a mandarinban nincs $[\propto] /[\varnothing]$, az $[\gamma]$ és a [ə] pedig allofónok, ezért itt is inkább a magyarok kiejtésének hangzásbeli „furcsaságáról” van szó, mintsem megértési problémákhoz vezető pontatlanságról.

- A mandarinbeli rotikus (retroflexált) [ð’]-t kiugróan nehéz elsajátítaniuk a magyaroknak, akik tipikusan a magyarból ,áthozott” [œr] (mint a magyar sör szóban) hangsorral helyettesítik. Ez is azonban inkább esztétikai problémája a kiejtésüknek, és nem vezet félreértésekhez.

\section{Mássalhangzók:}

- A kínai retroflex mássalhangzókat nehéz megfelelő pontossággal reprodukálniuk a magyar nyelvtanulóknak, percepciósan pedig nehezen különítik el a magyar palatoalveolárisoktól, de nem okoz nehézséget a más képzési helyủ mandarin mássalhangzóktól elválasztani őket.

- A mandarin alveoláris-palatális kettősen artikulált (la-dp) mássalhangzók produkciója és megkülönböztetése a magyar dorzopalatálisoktól, de - akárcsak a retroflexek esetében - nem nehéz a tanulók számára elválasztani őket a más képzési helyű mássalhangzóktól.

- A mandarin uvuláris approximáns $[\chi]$ percepciósan jól érzékelhető a magyarok számára (különösen a veláris változata: [x], amelyet jól ismerhetnek például a németből vagy az oroszból). Produkciósan azonban gyakran helyettesítik a magyar gégefői [h]-val, amely szokatlan hangzást eredményez, de (ismét csak) nem vezet megértési nehézségekhez.

\section{Félmagánhangzók és diftongusok:}

- A standard (budapesti) magyar köznyelvben lényegében nincsenek a szó szoros értelmében vett félmagánhangzós siklóhangok és így diftongusok sem. ${ }^{72}$ Ezzel nyilvánvaló összefüggésben a kínai diftongusokat gyakran

${ }^{72}$ Egyes kivételektől (például autó [avto:]) eltekintve. 
helyettesítik a magyar tanulók teljes értékü magánhangzók szekvenciáival, például [av] $\rightarrow$ [ao], [ja] $\rightarrow$ [ia], [wo] $\rightarrow$ [uo]. ${ }^{73}$ Ugyanakkor egyfelől ez a hiba sem vezet megértési problémákhoz, másfelől (az ELTE kínai nyelvtanárainak egybehangzó véleménye szerint) ha a tanár expliciten elmagyarázza a tanulóknak a különbség lényegét, akkor a magyar tanulók számára nem okoz problémát a megfelelő produkció sem.

\section{Tónusok és szótagszerkezet:}

- A kínai nyelv tónusainak puszta léte egészében az újdonság kategóriába esik, hiszen ez a jelenség teljesen hiányzik a magyarból. A tónus fogalmának és kategóriájának megismerése után pedig további problémaforrás a semleges tónus (tónustalanság) és a tónusmoduláció jelensége.

- A kínai nyelv jellemzően monoszillabikus, azaz a morfémák döntő többsége egy szótagú, míg ez nem áll a magyarra. Ez a tény, úgy véljük, további motivációt jelent a tanulók számára a diftongusok fentebb leírt szétbontására teljes magánhangzók szekvenciáivá.

\section{Hangsúly és intonáció:}

- A tónusok megléte a kínaiban megnehezíti a tanulók számára az intonáció érzékelését és produkcióját, olyannyira, hogy egyes magyar nyelvtanulók csak a tónusok megfelelő reprodukciójára koncentrálnak, teljesen figyelmen kívül hagyva az intonációs dallamokat. Ez ráadásul olyan hiányosság, amely már megértési zavarokhoz, félreértésekhez is vezethet, hiszen (mint fentebb láttuk) kijelentés és kérdés között nemegyszer csak az intonáció segít különbséget tenni.

73 Kicsit más (de talán még kevésbé problémás) a palatális kerekítetlen félmagánhangzó ügye, különösen a főmagánhangzót követő helyzetben: ennek a magyarban a dorzopalatális approximáns [j] mássalhangzó a legközelebbi megfelelője és gyakori helyettesítöje a tanulók kiejtésében. 


\section{3. Újrakódolás}

\section{Magánhangzók:}

- $\mathrm{Az}[\varepsilon, \mathrm{e}(\mathrm{:}), \mathrm{o}]$ magánhangzók mind önálló fonémákat képviselnek a magyarban, míg a mandarinban egyazon (középső nyelvállásra specifikált) fonéma kontextuálisan determinált allofónjai (leszámítva az [ $\varepsilon$ ] előfordulását az -ian [jen] rímben). Ez azonban tapasztalataink szerint nem vezet problémákhoz a magyarok kínainyelv-tanulásában (viszont valószínüsíthetően nehézség lehet magyarul tanuló kínaiak számára).

\section{Mássalhangzók:}

- A mandarin retroflex réshangoknak [S, z] a magyar palatális frikatívák [, 3$]$ a legközelebbi artikulációs megfelelői, ezért (nem meglepő módon) gyakran helyettesítik öket ezekkel. Az eredmény gyakran „furcsa” hangzás a kiejtésben, de értelmi zavarhoz ez nem vezet. ${ }^{74}$

- A mandarinban a veláris nazális [y] önálló fonémát reprezentál, míg a magyarban, bár ugyancsak létezik ez a hang, csupán az [n] allofónja [g, k] előtti helyzetben, így sosem fordul elő (szünet előtti) szótagvégen, hiszen mindig követi öt egy [g] vagy [k]. Nehézséget jelent a magyarok számára, hogy a veláris nazálist megtanulják önmagában kiejteni, utána álló [g] nélkül. Itt is igaz azonban, hogy a hibás *[yg] szótagzárlat inkább csak esztétikai probléma.

\section{Hangsúly és intonáció:}

- Míg a magyarban a (lexikális) szóhangsúly elhelyezése teljes mértékben megjósolható és automatikus (a szó első szótagján), addig a mandarinban a szóhangsúly sokkal gyakrabban esik a két és három szótagú egységek utolsó szótagjára, másfelől pedig számos szóban hangsúlytalan és tónustalan az utolsó szótag, és a hangsúly az utolsó előttire esik. Lényegében tehát (az angolhoz, oroszhoz stb. hasonlóan) a nyelvtanulóknak a kínaiban is szavanként kell megtanulniuk a hangsúly helyét. Ez azonban két

74 Megjegyzendő azért, hogy bár a standard mandarin hangtan ezeknél valóban retroflex artikulációt ír elö, ám a kínai beszélők tekintélyes része sem retroflexen ejti a [s] hangot (hanem apikális posztalveolárisként: Lee-Zee 2003), a [z] státusa pedig másképp problémás: ez sokak szerint nem is frikatíva, hanem approximáns (vö. 6. lj.). 
okból is csak kis horderejü probléma: egyrészt mivel az utolsó szótag hangsúlytalansága a két és három szótagú szavakban kéz a kézben jár e szótag tónustalanságával, ezért könnyü automatizálni a megjegyzést; másrészt pedig a különböző hangsúlyelhelyezési minták szinte sosem eredményeznek minimálpárokat, vagyis ennek a hibalehetőségnek sincs kockázata a megértés terén. ${ }^{75}$

\section{Konklúzió és összefoglalás}

E cikkünkben áttekintettük a mandarin kínai és a magyar nyelv fóbb hangtani jellegzetességeit, egyrészt számba véve a mássalhangzókat, magánhangzókat, félmagánhangzókat, tónusokat, szótagokat külön-külön a két nyelv vonatkozásában, másrészt pedig összevetve e kategóriákat és alrendszereket a két nyelvben. A kontrasztív elemzés lehetővé tette, hogy azonosítsuk azokat az eltéréseket, amelyek Prator nyelvtanulás-nehézségi hierarchiája szerint ${ }^{76}$ súlyo- $^{-}$ sabb problémákat okozhatnak a kínaiul tanuló magyaroknak. Sok tanár tartaná jó ötletnek ezt a megközelítést, amely jól meg is felelne a hagyományosabb strukturalista (,nyelvtan + fordítás”) és behaviorista nyelvtanítási módszereknek. Kiindulhatnának azokból a nyelvi elemekböl, amelyeket „könnyen elsajátíthatónak" kategorizálnak, és miután a tanuló ezeket valóban el is sajátítja, építőkövekként lehetne őket használni a további építkezéshez, a nehezebb elemek felé. Ám ez a megközelítés csak a felszínes szemlélő számára ennyire ígéretes, valójában azonban számos gyenge pontja van. A ,viszonylagos könnyüség” és ,viszonylagos nehézség” intuitív megítélése (például az anyanyelvi beszélők részéről) notóriusan megbízhatatlan. De még ha történetesen pontos lenne is, vagy ha elfogadnánk azt a tézist, hogy minél nagyobb az eltérés két nyelv egymásnak megfeleltethető elemei között, annál nagyobb az ebből eredő várható nehézség, és alapul vennénk a Prator-féle kategorizációból adódó skálát, akkor sem garantálná semmi, hogy egy erre épülő progresszív strukturális tanterv hatékony lesz. E tekintetben elég, ha felidézzük Dulay és Burt demonstrációját ${ }^{77}$ arról, milyen elképesztő különbség van az

75 Vannak azért hangsúlyalapú (csaknem) minimálpárok, például: 大意 dà.yì 'fö gondolat' vs. $\underline{\boldsymbol{d a}}$.yi 'gondatlan', de itt is igaz, hogy tónusérték-különbséggel is korrelál a hangsúlyminta különbsége (Duanmu 2007: 129).

76 Prator 1967.

77 Dulay-Burt 1974. 
angol mint idegen nyelv morfémáinak természetes elsajátítási sorrendje és a megtervezett nyelvkönyvi sorrendek között.

Egy ettől eltérö, tanulóközpontú megközelítés a tanulók saját prioritásaiból és elvárásaiból indulna ki, amelyek részben a célnyelvröl meglevő általános ismeretekből, részben pedig személyes tapasztalatokból erednek. Az egyéni motiváció és attitüdök alapvető fontosságát tekintve a tanulási folyamatokban, e megközelítés mellett sok érv szól. És valóban: központi oszlopa lett ez annak a befolyásos humanista oktatási-nevelési éthosznak, amely olyan jelentős XIX. századi alakokig nyúlik vissza, mint John Dewey, és az utóbbi fél évszázadban olyanok álltak ki mellette nagy sikerrel, mint Carl Rogers. ${ }^{78}$ Saját kérdéskörünkre alkalmazva: aki kínaiul (de akár bármilyen egyéb nyelven) tanul, aligha fog jelentős elörelépést elérni ebben, ha nincs arról meggyőződve, hogy amit meg kell tanulnia, az megéri a ráfordítást. Ám ez önmagában még nem kellő alap egy megbízható nyelvtanítási programhoz. A tanuló saját elképzelései és döntései lehetnek (részben vagy egészben) irreálisak vagy tévesek, és a tanár feladatkörébe tartozik, hogy utat mutasson neki ezen a téren.

Miközben a tanár kísérletet tesz erre, nagy valószínüséggel fog egyes utilitárius megfontolásokat hasznosnak találni: az instrumentális motiváció megteremthető és növelhető azzal, ha megmutatjuk a gyakorlati hasznát és értékét mindannak, ami megtanulandó. Ez a gondolat pedig elvezet minket ahhoz a kritériumhoz, amellyel kiválasztjuk a prioritást élvező hangtani jelenségeket. E kritérium röviden megfogalmazható így: „a kommunikációs hatékonyság lehetősége", illetve (ha már nehézséget okozó hangtani különbségekre fókuszálunk): ,a kommunikációs zavar elkerülésének a potenciálja”. Az ezt célzó döntések megfelelnek mind annak, hogy a tanuló érzékelt igényeit figyelembe vegye, mind pedig annak, hogy az intézmény (a mi saját esetünkben az ELTE) felelősen biztosítsa, hogy a diplomát szerző tanulók hatékony kommunikációra alkalmas nyelvtudással gazdagodjanak.

Ha most végigtekintünk a két nyelv különbségeinek fentebbi kategorizált listáján, akkor két olyan tételt találunk, amely egyaránt reprezentálja a potenciális tanulási nehézséget és a potenciális kommunikációs zavart: a tónusokat és az azokkal interferáló mondatintonációkat. Mindkettőt a Prator-féle , újdonság” kategóriába soroltuk (az előbbit a saját jogán, az utóbbit pedig az interferencia miatt), így nagyjából hasonló szintủ nehézségre számíthatnánk ezek tanításában-tanulásában. Mégis van köztük több lényegi különbség, ami pe-

78 Rogers 1969. 
dagógiai oldalon is manifesztálódik: (1) Az intonáció kérdése a kínaiban egy igen összetett és máig vitatott nyelvészeti kérdés: míg abban egyetértés van a kutatók között, hogy létezik, addig a pontos elemzése és leírása terén nincs egyetértés sok alapvetö kérdésben, például abban sem, hogy pontosan milyen a viszonya a tónusokkal. (2) Fonetikai kísérletekben is extrém nehézséget jelent a tonális és az intonációs hatások szétválasztása. (3) Bár mind a tónusok, mind az intonáció szerepet játszanak a jelentések elkülönítésében, az előbbiek fonémikus státusához képest az utóbbinak a szerepe e téren jóval kevésbé pervazív és megkerülhetetlen. Mindezek alapján aligha lehet kérdéses, hogy a kínai mint idegen nyelv magyar anyanyelvüeknek történő tanításában a tónusok rendszere az hangtani elem, amelyre a legtöbb figyelmet kell fordítani.

\section{Felhasznált másodlagos szakirodalom}

Ameka, Felix 1992. „Interjections: The universal yet neglected part of speech.” Journal of Pragmatics 18: 101-118. https://doi.org/10.1016/0378-2166(92)90048-G

Chao Yuen Ren 赵元任 1929. Beiping yudiao de yanjiu 北平语调的研究. Függelék A. A. Milne: The Camberley Triangle cimü müvéhez. Shanghai: Zhonghua Shuju 中华书局. Chao, Yuen Ren 1948. Mandarin Primer. An Intensive Course in Spoken Chinese. Cambridge, MA: Harvard University Press. https://doi.org/10.4159/harvard.9780674732889

Chao, Yuen Ren 1968. A Grammar of Spoken Chinese. Berkeley: University of California Press.

Chao, Yuen Ren 1976. Rhythm and structure in Chinese word conceptions. In: Dil, Anwar S. (ed.), Aspects of Chinese Sociolinguistics: Essays by Yuen Ren Chao. Stanford, CA: Stanford University Press, 275-292.

Chao Yuen Ren 赵元任 1983. Tongzi Fang'an 通字方案 (A Project for General Chinese). Beijing: Shangwu Yinshuguan.

Chappell, Hilary - Li Lan 2017. Mandarin and other Sinitic languages. In: Chan, SinWai (ed.), Routledge Encyclopedia of the Chinese Language. Oxford: Routledge, 605-628.

Chen, Yiya - Carlos Gussenhoven 2015. „Shanghai Chinese.” Journal of the International Phonetic Association 45/3: 321-337. https://doi.org/10.1017/S0025100315000043

Crystal, David 1995. Documenting rhythmical change. In: Lewis, J. (ed.), Studies in General and English Phonetics: Essays in Honour of Professor J. D. O'Connor. London: Routledge, 174-179.

Duanmu, San 2007. The Phonology of Standard Chinese. (2. javított kiadás.) Oxford: Oxford University Press. 
Dulay, Heidi - Marina Burt 1974. „Natural sequences in child second language acquisition.” Language Learning 24: 37-53. https://doi.org/10.1111/j.1467-1770.1974.tb00234.x

Gósy Mária 2004. Fonetika, a beszéd tudománya. Budapest: Osiris Kiadó.

He Yang 贺阳- Jin Song 劲松 1992. Beijinghua yudiao de shiyan tansuo 北京话语调的试 验探索 [Intonations of the Beijing dialect: an experimental exploration]. Yuyan Jiaoxue Yu Yanjiu 语言教学与研究 2: 71-96.

Hu Mingyang 胡明扬 1987. Beijinghua Chutan 北京话初探. Beijing: Shangwu Yinshuguan.

Huang Borong 黄伯荣- Liao Xudong 廖旭东 1991. Xiandai Hanyu 现代汉语. Beijing: Gaodeng Jiaoyu Chubanshe.

Jespersen, Otto 1924. The Philosophy of Grammar. London: Allen and Unwin.

Kálmán László - Nádasdy Ádám 1994. A hangsúly. In: Kiefer F. (szerk.) 1994: 393-467.

Kiefer Ferenc (szerk.) 1992. Strukturális magyar nyelvtan 1. - Mondattan. Budapest: Akadémiai Kiadó.

https://doi.org/10.1556/9789630596787

Kiefer Ferenc (szerk.) 1994. Strukturális magyar nyelvtan 2. - Fonológia. Budapest: Akadémiai Kiadó.

https://doi.org/10.1556/9789630598033

Kiefer, Ferenc - Katalin É. Kiss. (eds.) 1994. The Syntactic Structure of Hungarian. Syntax and Semantics 27. San Diego - New York: Academic Press. https://doi.org/10.1163/9789004373174_009

Kornai, András 1994. On Hungarian Morphology (Linguistica, Series A: Studia et Dissertationes 14.) Budapest: MTA Nyelvtudományi Intézet.

Ladefoged, Peter - Ian Maddieson 1996. The Sounds of the World's Languages. Oxford: Blackwell.

Lee, Wai-Sum - Eric Zee 2003. „Standard Chinese (Beijing).” Journal of the International Phonetic Association 33: 109-112. https://doi.org/10.1017/S0025100303001208

Li, Fang-Kuei. 1973. „Language and dialects in China.” Journal of Chinese Linguistics 1: $1-13$.

Li Rulong 李如龙 2007. Hanyu Fangyanxue 汉语方言学. Beijing: Gaodeng Jiaoyu Chubanshe 高等教育出版社.

Lin Maocan 林茂灿 2004. Hanyu yudiao yu shengdiao 汉语语调与声调. Yuyan Wenzi Yingyong 语言文字应用 3 .

Lin Tao 林奉 1996. Yuyin yanjiu he duiwai Hanyu jiaoxue 语音研究和对外汉语教学. Shijie Hanyu Jiaoxue 世界汉语教学 3.

Lin, Yen-Hwei 2007. The Sounds of Chinese. Cambridge: Cambridge University Press.

Lu Jianji 鲁健䩀. 2010. „Duiwai Hanyu yuyin jiaoxue jige jiben wenti de zai renshi 对外汉语语音教学几个基本问题的再认识”. Dalian Xueyuan Xuebao 大连学院 学报 5: 1-4.

Luo Changpei 罗常培- Wang Jun 王均 2002. Putong Yuyanxue Gangyao (Xiuding Ben) 普通语音学纲要 (修订本). Beijing: Shangwu Yinshuguan, 156-157.

Mair, Victor H 1991. What Is a Chinese "Dialect/Topolect"? Reflections on Some Key Sino-English Linguistic Terms. Sino-Platonic Papers 29. http://www.sinoplatonic.org/complete/spp029_chinese_dialect.html. Utolsó hozzáférés: 2020. 04. 09. 
Mair, Victor H. 2013. The Classification of Sinitic Languages: What Is "Chinese"? In: Cao G. et al. (eds.): Breaking Down the Barriers: Interdisciplinary Studies in Chinese Linguistics and Beyond. Taipei: Academia Sinica, 735-754.

Matisoff, James A. 2003. Handbook of Proto-Tibeto-Burman: System and Philosophy of Sino-Tibetan Reconstruction. Berkeley, L.A., London: University of California Press.

Nádasdy, Ádám 1985. Segmental phonology and morphophonology. In: Kenesei, István (ed.): Approaches to Hungarian Vol.1. Szeged: JATEPress, 225-246.

Norman, Jerry 1988. Chinese. Cambridge: Cambridge University Press.

Prator, Clifford 1967. Guidelines for planning classes and teaching materials. Working

Papers in English as a Second Language. Matter, Methods, Materials. Los Angeles:

Department of English, University of California.

Pulleyblank, Edwin 1984. Middle Chinese: A Study in Historical Phonology. Vancouver: University of British Columbia Press.

Ramsey, S. Robert 1987. The Languages of China. Princeton, N.J.: Princeton University Press.

Roach, Peter 1982. On the distinction between stress-timed and syllable-timed languages. In: David Crystal (ed.): Linguistic Controversies. London: Edward Arnold, 73-9.

Rogers, Carl 1969. Freedom to Learn: A View of What Education Might Become. Columbus, OH: Charles E. Merrill.

Seikel, Anthony, Douglas King and David Drumright. 2010. Anatomy \& Physiology for Speech, Language and Hearing (4th ed.), Cliffon Park, NY: Delmar Language Learning. Shen Jiong 沈炣. 1994. „Hanyu yudiao gouzao he yudiao leixing 汉语语调构造和语调 类型.” Fangyan 方言 3: 221-228.

Shen, Susan Xiaonan 1989. „Interplay of the four citation tones and intonation in Mandarin Chinese." Journal of Chinese Linguistics 17.1: 61-73.

Siptár Péter 1994. A mássalhangzók. In: Kiefer F. (szerk.) 1994: 183-272.

Siptár, Péter - Miklós Törkenczy. 2000. The Phonology of Hungarian. Oxford: Oxford University Press.

Thurgood, Graham - Randy J. LaPolla 2017. The Sino-Tibean Languages. (2. edition.) London-New York: Routledge.

Varga László 1994. A hanglejtés. In: Kiefer F. (szerk.) 1994: 468-549.

Wu Zongji 吴宗济 1997. Cong shengdiao he yuelü de guanxi tichu putonghua yudiao chuli de xin fangfa 从声调和乐律的矢系提出普通话语调处理的新方法. Qingzhu Zhongguo Shehuikexueyuan Yuyanyanjiusuo Jiansuo 45 Zhounian Xueshu Lunwenji 庆祝中国社 会科学院语言研究所建所45周年学术论文集. Beijing: Shangwu Yinshuguan.

Xu Shirong徐世荣 1980. Putonghua Yuyin Zhishi 普通话语音知识. Beijing: Wenzi Gaige Chubanshe.

Zhu Xiaonong 朱晓农 2008. Yuyinxue 语音学 [Phonetics]. Beijing: Shangwu Yinshuguan. 